\title{
Kafkas Dağları İçin Yeni Araştırma Eğilimleri: Bibliyometrik Bir Analiz
}

\author{
New Research Trends for the Caucasus Mountains: A Bibliometric Analysis \\ İsmet Güney*a, Merve Altundal Öncü̈ ${ }^{\text {}}$, Mehmet Somuncu ${ }^{c}$
}

\begin{tabular}{l} 
Makale Bilgisi \\
\hline DOI: \\
10.33688/aucbd.710750 \\
\hline Makale Geçmişi: \\
Geliş: 28.03.2020 \\
Kabul: 16.05.2020 \\
\hline Anahtar Kelimeler: \\
Bibliyometri \\
Ağ Analizi \\
VOSviever \\
Dağlık Alan Araştırmaları \\
Kafkas Dağları \\
\end{tabular}

\begin{tabular}{l} 
Article Info \\
\hline DOI: \\
10.33688/aucbd.710750 \\
\hline Article History: \\
Received: 28.03 .2020 \\
Accepted: 16.05 .2020 \\
\hline Keywords: \\
Bibliometry \\
Network Analysis \\
VOSviever \\
Mountain Area \\
Researches \\
Caucasus Mountains
\end{tabular}

\begin{abstract}
$\ddot{O} z$
Araştırmada, Kafkas Dağları'nı konu alan uluslararası çalışmalar bibliyometrik olarak incelenmiştir. Burada amaç, Kafkas Dağları çalışmalarında lider aktörler ve yeni kavramlar ele alınarak yeni araştırmalara bir yol göstermektir. Araştırmada şu temel soruya yanıt aranmıştır: Kafkas Dağları konusundaki literatürünün mevcut gelişimi nasıldır ve gelecekte nereye evirilecektir? Tali sorular ise; Kafkas Dağları konusundaki, temel kavramlar ve yeni temalar nelerdir, hangi ülkeler ilgilenmektedir, atıf odakları hangi yazarlardır, yeni iş birliği odakları nerelerdedir ve disipliner dağllış nedir? Araştırma soruların yanıtlanabilmesi için bibliyometrik ăg analizi tekniği kullanılmıştır. Sonuçlarına göre yayın sayısı bakımından en önemli ülkeler ABD, Rusya ve Gürcistan'dır. Yayınların alansal dă̆llışı incelendiğinde 327 eserden 251'i doğa bilimleri ve mühendislik alanlarında olduğu tespit edilmiştir. Dolayısıla Kafkas Dağları araştırmalarında sosyal bilimler yetersizdir. Kafkas Dă̆ları'nın bölge ülkelerinde ortak bir mekânsal birimi olmasına rağmen analizlere göre iş birliği düzeyi düşüktür. Bu sonuçlarla Kafkas Dağları'nın kalkınması için multi-disipliner bir bilim anlayışının ve birlikte yönetim mekanizmalarının önemi bir kez daha düşünülmelidir.
\end{abstract}

\begin{abstract}
In the research, international studies on the Caucasus Mountains were examined bibliometrically. The research aimed to answer the following basic question: What is the current development of its literature on the Caucasus Mountains and where will it evolve in the future? The secondary questions are; What are the main concepts and new themes in the Caucasus Mountains, which countries are interested, which authors are the citational focus, where are the new collaborational focuses and what is their disciplinary distribution? In the research bibliometric network analysis technique was used. According to the results, the most important countries in terms of the number of publications are the USA, Russia and Georgia. When examining the spatial distribution of the publications, 251 out of 327 works were determined in the fields of natural sciences and engineering. Although the Caucasus Mountains have a common spatial unit in the countries of the region, the level of cooperation is low according to analysis.
\end{abstract}

\footnotetext{
*Sorumlu Yazar/Corresponding Author: ismetguney@ kilis.edu.tr

a Kilis 7 Aralık Üniversitesi, Fen-Edebiyat Fakültesi, Coğrafya Bölümü, Kilis/Türkiye, http://orcid.org/0000-0003-4682-4905

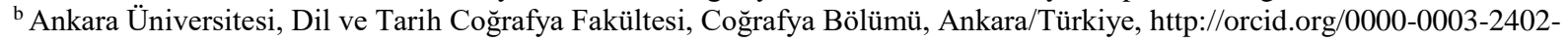
9134

c Ankara Üniversitesi, Dil ve Tarih Coğrafya Fakültesi, Coğrafya Bölümü, Ankara/Türkiye, http://orcid.org/0000-0001-88900537
} 


\section{Giriş}

Yeryüzünün yaklaşık \% 24'ü dağlık alanlar olmakla birlikte bu alanlarda dünya nüfusunun \% 10'u yaşamaktadır. Çünkü lokal ölçekte bu alanlarda beşeri ve ekonomik faaliyetlerin oldukça sınırlı olduğu söylenebilir. Ancak bu alanlar başta su olmak üzere, enerji, madenler, biyoçeşitlilik, orman ürünleri, tarım ürünleri ve rekreasyon faaliyetleri için küresel nüfusun \%40'1ndan fazlası için kilit bir role sahiptir (Beniston, 2000; Dal ve Gönençgil, 2018) Dolayısıyla dağlık alanlar günümüz koşullarında artan bir çevresel tahribat ve değişimle karşı karşıyadır (Somuncu, 2004). Mekânsal bir birim olarak da dağlık alanlardaki söz konusu değişim ve dönüşümle ilgilenen bilim dallarından biri coğrafya olmuştur. Fiziki coğrafya alanındaki çalışmalar, jeomorfoloji (özellikle erozyon ve ufalanma), klimatoloji (özellikle iklim değişikliği), hidroloji ve biyocoğrafya konuları üzerinde yoğunlaşırken, beşeri coğrafya alanındaki çalışmalar ise sürdürülebilirlik çerçevesinde, su temini, ormanların kullanımı, dağlarda turizm yönetimi, ekoturizm, korunan alanlar ve arazi kullanımı ve bunların yönetimi konuları öne çıkmaktadır (Mountain Agenda, 1998,1999; Payne vd., 2002). Bu bağlamda bir araştırma alanı olarak dağlık alanlar hızla değişen günümüz koşullarında farklı araştırma konularının ilgi odağındadır. Söz gelimi literatürde son yıllarda Kafkas Dağları'na olan ilginin arttığı görülmektedir (Şekil 1). Büyük bir bölümü dağlık alanlarla kaplı olan Kafkasya, gerek tarihsel gerekse coğrafi özellikleri bakımından insanlar için geçmişte olduğu gibi bugün de önemli bir yerdir. Bu bağlamda bir zaman ve mekân birimi olarak Kafkas Dağları üzerinde meydana gelen özgün olay ve olgular bilim insanları tarafindan araştırılmaktadır. Dolayısıyla uzun dönemli bilim literatüründe bu alanla ilgili pek çok çalışma bulunmaktadir.

Şüphesiz uzun dönemli bilim literatürü araştırma konularının değişimleri hakkında bazen gizil bazen de açık olarak evreleri ve ele alış biçimlerinin değişimini göstermektedir. Fakat bilim dünyasında özellikle son yıllarda dağlık alanlar gibi spesifik konuların ele alınışı ve gelişimi araştırma alanının nereye doğru gittiği ve gidebileceği ile ilgili bibliyometrik bir çok teknikle farklı çalışmalar yapılmaktadır (Kuhzady ve Benli, 2017; Kulak ve Cetinkaya, 2018; Kulak vd., 2019). Bu analiz tekniği bazen yayınlar üzerinden de dergilerin gelişimini ve değişen perspektifleri ortaya koymak için kullanılmaktadır (Estevao vd., 2017; Hall, 2011; Karagöz ve Kozak, 2014; Mckercher, 2008). Bazen de analiz tekniğinin objesi disiplinin tamamı olmaktadır (Bekaroğlu ve Yavan, 2013; Ertoy ve Yalçın, 2017; Güney ve Somuncu, 2017; Kervankıran vd., 2019). Bu tür araştırmalarda özellikle bibliyometrik ağ analizi, bilimsel yayınların yeni eğilimlerini belli konular, dergiler, yazarlar, kurumlar ya da ülkeler arasındaki ilişkilerin görselleştirilmesi yoluyla belirlenmesi bakımından tercih edilen en önemli tekniktir (Morris ve Van Der Veer Martens, 2008; Van Eck ve Waltman, 2010).

$\mathrm{Bu}$ araştırmada, bilimsel bir obje olarak Kafkas Dağları'nı araştıran uluslararası çalışmaların makro ölçekte konuları, disipliner dağılışı, bölgesel dağılışı ve atıf örüntüsü analiz edilmiştir. Bu çalışmayla, Kafkas Dağlarıyla ilgili araştırmalarda lider aktörler ve yeni kavramlar incelenerek ilgili alanda çalışan gerek coğrafya bilimi içerisinde gerekse dışındaki, yeni araştırmacılara yol göstermek hedeflenmektedir. Başka bir deyişle, Kafkas Dağları konusunda çalışan araştırmacılar için literatürde hangi konularda boşluk olduğu, hangi konularda hangi araştırmacıların yol gösterici olduğu ve hangi kavramların öne çıktığının gösterilmesi amaçlanmıştır. Araştırmanın bir diğer hedefi ise somut göstergeler ile literatürde örtük olan bir bilgiyi bibliyometrik ağ analizi yoluyla keşfetmektir. Bu 
bağlamda araştırma boyunca şu temel soruya yanıt aranmıştır: Kafkas Dağları konusundaki literatürün mevcut gelişimi nasıldır ve gelecekte nereye evirilecektir? Söz konusu araştırma sorusunun yanıtlanması için aşağıda yer alan alt sorular araştırılmıştır: Hangi ülkelerdeki araştırmacılar Kafkas Dağları'yla ilgilenmektedir? Kafkas Dağları konusundaki temel kavramlar ve yeni temalar nelerdir? Araştırmaların veya araştırmacıların mekânsal dağılışı ve disipliner dağılışı nedir? Kafkas Dağları konulu araştırmalarda atıf odakları hangi yazarlardır ve yeni iş birliği odakları nerelerdedir?

$\mathrm{Bu}$ soruların yanıtlanabilmesi için bibliyometrik göstergeler yoluyla ağ analizleri yapılmıştır. Verilerin temini için önemli bir indeks olan Scopus veri tabanından yararlanılmıştır. Veri tabanında "Kafkas Dağları" kelimesi içeren "makale başlığı, özet ve anahtar kelimeler" bölümlerindeki makaleler listelenmiştir ve analiz edilmiştir. Analiz sonuçlarına göre elde edilen bulgular aktörler ve kavramlar bağlamında değerlendirilmiştir. Araştırmanın amaçları ve yöntemi bakımından yapılan literatür taramasında alana ilişkin benzer herhangi bir çalışmaya rastlanmamıştır. Bu nedenle araştırmanın en önemli motivasyonu Kafkas Dağları ile ilgili bibliyometrik analiz yöntemiyle daha önce yapılan bir literatür analizi çalışması olmamasıdır. Sonuç olarak araştırmadan çıkacak olan sonuçlar literatürdeki yeni konu ve boşlukları göstermesi bakımından yeni araştırmalar için bir yol gösterici olabilir.

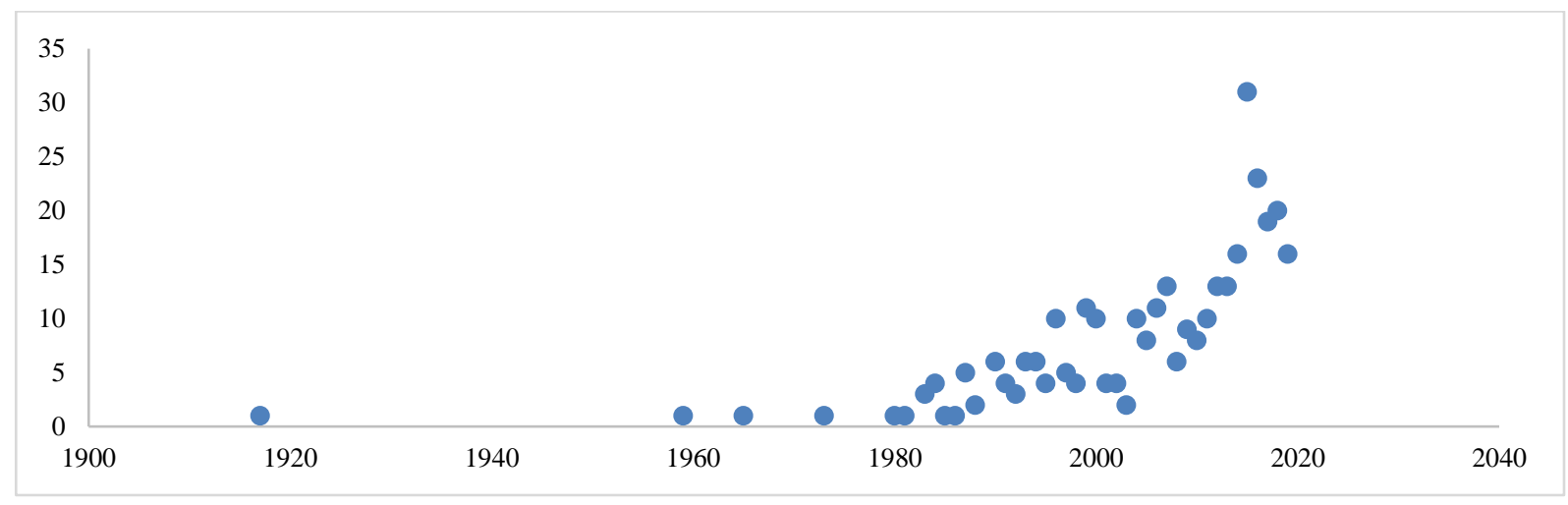

Şekil 1. Scopus'ta özet, başlık ve anahtar kelimeler bölümünde “Kafkas Dağları” teriminin geçtiği eserlerin yıllara göre dağılış1

\section{Veri, Yöntem ve Analiz}

Bu bölümde araştırma sorusu ve amacı doğrultusunda veri ve yöntem seçiminin nasıl yapıldığ1 ve analizlerin nasıl yorumlandığı açıklanmıştır (Şekil 2). 


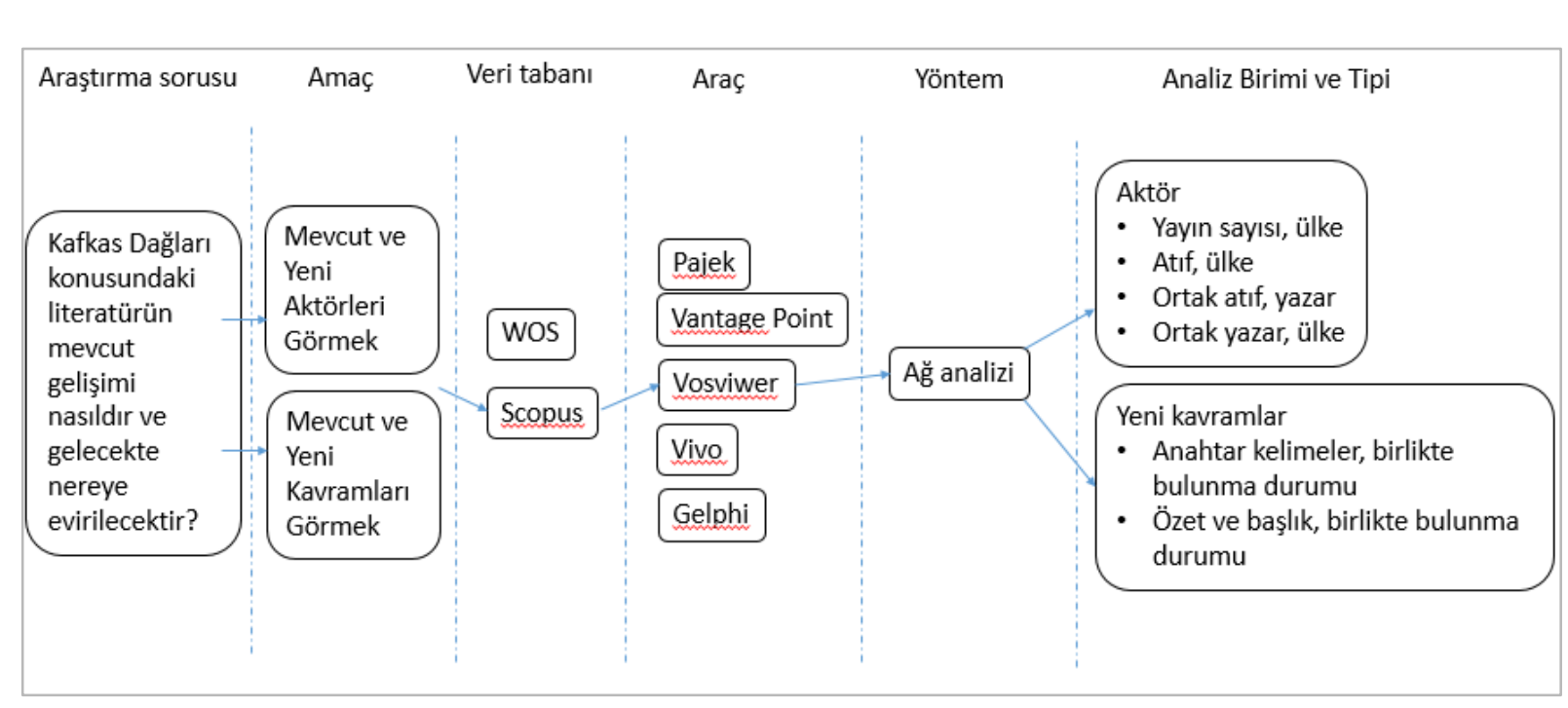

Şekil 2. Araştırma matrisi

Araştırmanın bibliyometrik göstergeler ile yürütülmesi daha nesnel bulgu ve sonuçlara ulaşılmasını sağlamaktadır. Bu bağlamda Kafkas Dağları olgusuna yönelik yeni eğilimlerin değerlendirilebilmesi için yayınların içerik, yazar ve orijin bilgilerine ilişkin veriler elde edilmelidir. $\mathrm{Bu}$ durumda araştırma verileri için iki veri seti seçeneği bulunmaktadır: Web of Science (Wos) ve Scopus veri tabanları. Wos' ta «Kafkas Dağları» kelimesi özet, başlık ve anahtar kelimeler bölümünde yer alan 235 eser bulunmuştur. Buna karşın Scopus'ta ise 327 eser bulunmuştur. Veri setleri arasındaki bir diğer fark ise Wos genellikle doğa bilimlerinden çalışmalara yer veren bir sonuç çıkarmıştır. Scopus'taki alansal dağılış ise daha heterojen bir yapıdadır (Şekil 3). Bu nedenle araştırmada farklı bakış açılarını sunması bakımından Scopus atıf indeksi seçilmiştir. Veri tabanında 2 Ekim 2019 tarihinde yapılan «caucasus mountains» kelimesinin başlık, özet ve anahtar kelimeler bölümlerinde yer aldığ 327 doküman (270 makale, 22 kitap bölümü, 16 konferans bildirisi, 14 inceleme, 3 kitap) elde edilmiştir. 


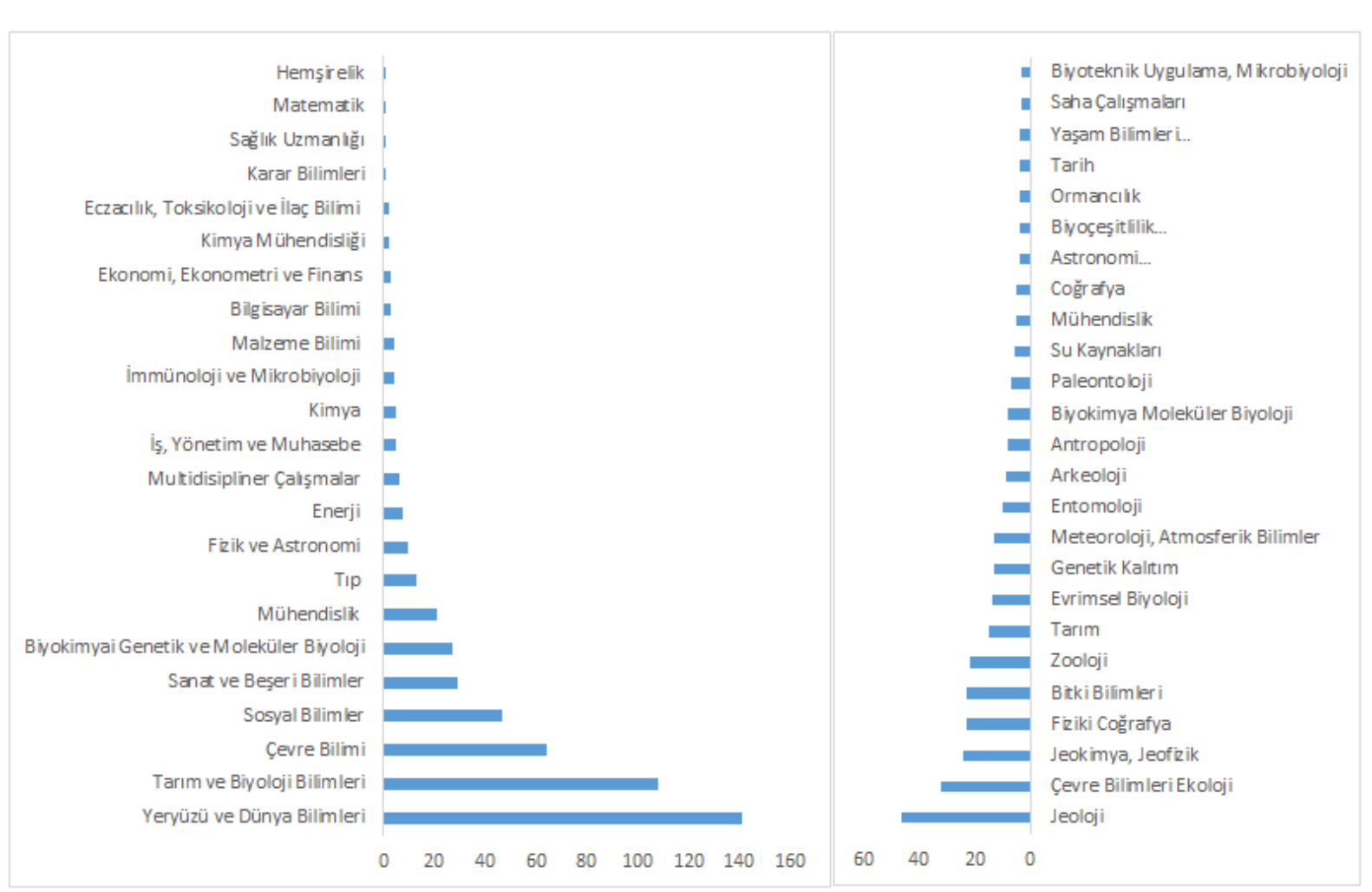

Şekil 3. Scopus (Solda) ve Wos (Sağda) veri tabanlarında Kafkas Dağları'yla ilgili yayınların alansal dağılımı

Söz konusu verileri değerlendirmek amacıyla ağ analizi yöntemi kullanılmıştır. Sosyal bilimlerde ağ analizi, kişilerin, kurumun veya nesnenin sosyal sistem içerisindeki ilişkilerini biçimsel olarak ve bu ilişkilerin sosyal yapıdaki yer ve zaman boyutundaki değişimlerini incelemek için birçok alanda sıklıkla başvurulan bir görselleştirme yöntemidir (Al vd., 2012; Tindall ve Wellman, 2001). Dolayısıyla ağ analizi, hem sosyal aktörleri hem de bu aktörlerin arasındaki ilişkileri ortaya çıkarmaktadır (Yüncü ve Kozak, 2012). Bibliyometrik ağ analizi ise, belirli bir disiplin ya da alanda araştırma konuları, yazarlar ve kurumlar arası ilişkilerin incelenmesi ile bu ilişkinin ne şekilde olduğunun gösterilmesi ve yorumlanmasında kullanılan bir yaklaşımdır (Scott, 2000). Ağ analizi, evreni oluşturan, aynı zamanda analiz birimi de olan dügüumler (node) ve dügümleri birbirine bağlayan kenarların (edge $)^{1}$ ilişkilerinden oluşmaktadır. $\mathrm{Bu}$ sayede örtük olan ilişkiler görselleştirilerek modellenir (Al vd., 2012; Freeman, 2004). Bu bağlamda bir bibliyografik yöntem olarak sosyal ağ analizi, ortak yazarlık durumu ve kurumlar arası işbirliği gibi birbirine bağlı ağlar arasındaki ilişkilerin çıkarılması, bu ağ içerisinde ön plana çıkan aktörlerin (yazar, kurum vb.) ortaya çıkarılmasında oldukça önemli bir rol oynamaktadır (Metin, 2013). Bu araştırmada yöntem olarak ağ analizinin seçilmesinin nedeni ise, literatürün devamlı ve birikimsel özelliğinden dolayı kavranmakta zorlanılan bütünsel ve zamansal boyutu etkili bir şekilde özetleyecek olmasıdır. Bu nedenle yeni eğilimleri araştıran birçok çalışmada bilimsel yayınların belli konular, dergiler, yazarlar, kurumlar ya da ülkeler arasındaki ilişkilerin görselleştirilmesi yoluyla belirlenmesi bakımından tercih edilmiştir (Morris ve Van Der Veer Martens, 2008; Van Eck ve Waltman, 2010). Araştırma sorularının yanıtlanabilmesi için temin edilen bibliyometrik veriler ağ analizi yöntemi olan VOSviewer v.1.61 (Centre for Science and Technology Studies) programı kullanılarak analiz edilmiştir. VOSviewer, bibliyometrik verilere ilişkin ağların 
görselleştirilmesi için tasarlanmış bir bilimsel haritalama programıdır. Bu programda kelime eşbulunma analizi ve eş-yazarlık analizlerinin yanı sıra atıf ağlarının görselleştirilmesi gibi birçok bibliyometrik ağ analizi gerçekleştirebilmektedir. VOSviewer, uzaklık temelli görselleştirme yaklaşımına dayalı olarak bibliyometrik ağları görselleştirmektedir. VOSviewer bilgi görselleştirmesinde programa özel geliştirilmiş olan VOS (Visualization of Similarities) algoritmasını kullanmaktadır. Bu algoritmayla bibliyometrik veri setleri içinde oluşturduğu belirlenen parametrelere bağlı olarak küme ve kümeler arasında bağlantıları ağ ve yoğunluk haritaları (heat map) ile görselleştirmektedir.

Araştırmanın amacı doğrultusunda elde edilen birinci tip veriler atıf, yazar ve adres bilgilerini içeren bibliyometrik verilerdir. Bu veriler farklı analiz birimlerinde farklı analiz türlerine uygulanmıştır. Bu kapsamda;

-Ülkeler ortak yazarlık (co-authorship) durumuna göre,

-Ülkeler aldıkları doğrudan atıf (citition) durumuna göre,

-Yazarlar ortak atıf (co-citition) durumuna göre analiz edilmiştir.

Araştırma amacı doğrultusunda elde edilen ikinci tip veriler, eserlerin konularına ilişkin başlık, özet ve anahtar kelimelerden oluşan metin/içerik verileridir.

-Başlık ve özet bölümünde kullanılan kavramlar/terimler çeşitli varsayımlar altında birlikte kullanımına/bulunmasına (co-occurance) göre terimsel kavramlar elde edilmiştir.

-Aynı şekilde anahtar kelimeler, birlikte kullanımına/bulunmasına (co-occurance) göre analiz edilmiş ve bazı terimsel kavramlar elde edilmiştir.

VOSviewer yardımıyla görselleştirilmiş bulgular sıklık, ilişkisellik, kümelenme ve zaman analizine göre yorumlanmıştır. Sıklık, varsayımlar sonucu elde edilen ağ haritalarında analiz birimlerini oluşturan metin ve bibliyometrik verilerin görülme sıklığıdır. Bu ilke basit anlamda bir birimin analiz içerisinde kaç kez kullanıldığıdır. İlişkisellik ise sıklık ile belirlenen bibliyometrik veriler arasında ilişkisellik düzeyini, yani birlikte bulunma durumunu ifade etmektedir. Buna göre yüksek ilişkiselliğe sahip birimler program tarafından ağ haritasına aktarılırken, ilişkiselliğin düşük olduğu birimler hariç tutulmuştur. İlgi düzeyi yüksek olan bibliyometrik verilere örnek olarak verilebilecek olan terimler; metin verileri tarafından kapsanan belirli konuları temsil etme eğilimindeyken, ilgi düzeyi düşük olan terimler genel bir yapıya sahiptir ve belirli bir konuyu temsil etmeme eğilimindedir. İlgi düzeyi düşük olan terimleri hariç tutarak, genel terimler filtrelenir ve odak daha belirgin ve daha bilgilendirici terimlere geçer. Ardından küme analizinde ise düğüm denilen aktörler/birimler ve bu düğüm çiftlerini birbirine bağlayan ilişkiler analiz edilmektedir. Tüm düğümlerin ve ikili düğümler arasındaki ilişkilerin oluşturduğu küme sosyal ağ olarak adlandırılmaktadır. Dügümler, kişi, grup, kurum veya ülke olabilir. İlişkiler ise bu düğümlerin birbirleriyle olan ortak çalışmalarıdır. (Al ve ark.,2012; Tindall ve Wellman, 2001). Son olarak zaman trendi analizi ile dönemsel olarak öne çıkan konuların diğer dönemlerde ilerleyişi ve yarattığı tematik alanlar harita üzerinde gösterilmektedir. Tematik alan, farklı dönemler boyunca gelişim geçiren temalar grubu olarak tanımlanabilir. Burada öne çıkan tematik alanların belirlenmesinde yayınlanma tarihleri kullanılmaktadır. Bu durumda zamansal boylam analizi mümkün 
olmaktadır. Örneğin bir gelişim haritası, tematik alanların birbirini takip eden dört dönemde, farklı dönemlerin araştırma temaları arasındaki kavramsal bağın tespit edilmesini sağlamaktadır (Yıldız ve Aykanat, 2017).

\section{Bulgular}

\subsection{Kafkas Dağları Araştırmalarında Lider Aktörler ve Yeni Aktörler}

Araştırma Kafkas Dağları olgusunun literatürdeki gelişimini incelemektedir. Dolayısıyla araştırma sonuçları araştırma olgusunun gelecek durumuyla ilgili bir tahmin yapmaya imkân vermektedir. Bu bağlamda ilk elde edilen bulgu, araştırma konusunda en çok çalışan aktörlerin tespiti olmuştur. Bu bağlamda yapılan analizler şunlardır: Yayın sayısı, atıf sayısı ve atıf ağ haritası, ortak yazar ağ haritası ve ortak atıf ağ haritası. Bu analizler sayesinde araştırmalarda lider ülke, kurum veya yazarlara ilişkin tespitler yapılmıştır.

Garfield (1979) yayın ve atıf sayılarının bilimsel dergilerin performansını değerlendirmede başat bir rol oynadığını belirtmektedir. Bu bağlamda ilk olarak, bir kurumun akademik başarısının tespiti için en temel verilerden biri olan yayın sayısı analiz edilmiştir. Veri tabanında «caucasus mountains» kelimesinin başlık, özet ve anahtar kelimesi bölümlerinde yer aldığı 327 doküman elde edilmiştir. Bu veriler birinci yazarların sorumlu olduğu kurumların bulunduğu ülkeye göre dağılımı yapıldığında önde gelen ülkeler 98 yayınla $A B D$ ve 94 yayınla Rusya olmuştur. Ardından gelen ülkeler ise Gürcistan (40), Almanya (29), İngiltere (28), Fransa (25) ve Türkiye (17) olmuştur. Bu bulgu temel anlamda araştırma sahası hakkında bilgi üreten ve bilginin yoğunlaştığı coğrafi bölgelere işaret etmektedir. Aynı zamanda bu analizden çıkan sonuçlar diğer analizleri etkileyecek bir faktör olarak görülmektedir (Şekil 4). 


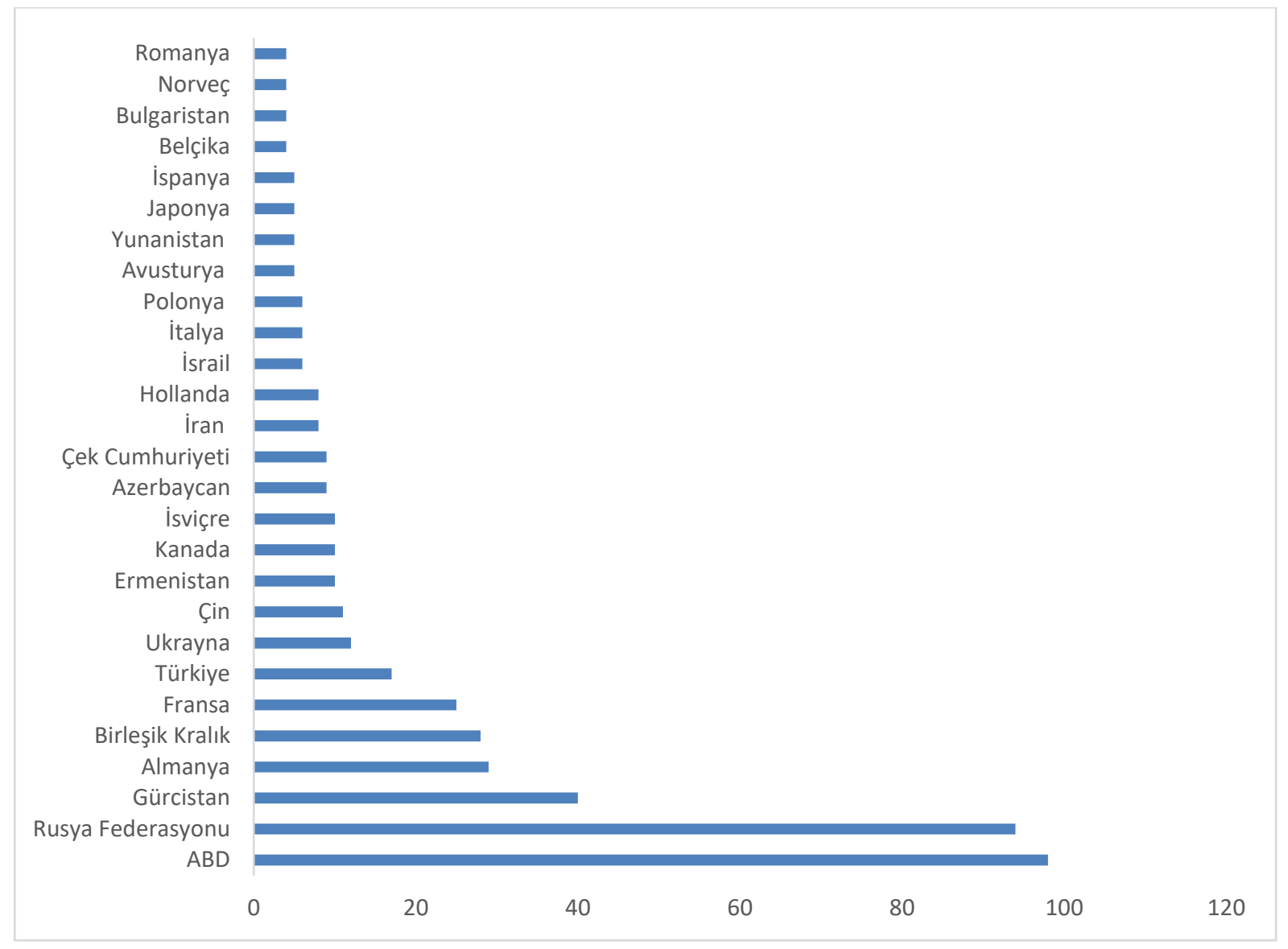

Şekil 4. Kafkas Dağları konusunda en çok yayın yapan ülkeler

Grafiğe göre Kafkas ülkeleri araştırma sahasına diğer ülkelerden daha az ilgi olduğu görülmektedir. Bu durum ise bölgedeki bilimsel çalışma pratiklerine ve iş birliği düzeyine bağlanabilir. Bölgedeki bilimsel çalışma pratikleri incelendiğinde araştırmaların mikro ölçekte kaldığı ve Kafkas Dağları'nı kapsayacak düzeyde olmadığı görülmektedir. Örneğin Ayan vd. (2009)' nin, Kafkas Dağları'nın bir parçası olan Doğu Karadeniz Dağları'nda yapmış oldukları çalışma ölçekli ve uluslararası iş birliği olmayan bir çalışma olduğundan araştırma başlığı, özeti ve anahtar kelimeleri içerisinde Kafkas Dağları yer almamaktadır. Bir diğer faktör olan iş birliği düzeyi ise bölgede neden mezo veya makro ölçekte çalışılmadığını gösterir. Buna göre bölgede tarihsel olarak varlığını sürdüren politik çekişmelerin, araştırmacıların bölgedeki diğer ülkelerle iş birliği yapmasına engel oluşturduğu düşünülmektedir. Pek çok farklı ülkenin dahil olduğu Kafkas Dağları, bölge ülkeleri arasındaki iş birliğinin düşük olması nedeniyle kapsamlı olarak ele alınamamakta ve daha az çalışılmaktadır. Ancak en çok yayın yapan ABD dikkate alındığında, bölge ülkelerinden araştırmacıların ABD’li araştırmacılarla iş birliği yapmasına bağlı olarak üst sırada yer aldığı söylenebilir.

Günümüzde bilimsel yayınların ne kadar atıf aldığı, performansın ölçümünde sıklıkla kullanılan bir diğer göstergedir (Al, 2008). Atıf analizinin bir diğer özelliği ise karşılıklı fikirlerin aktarımını ve dolaşımını göstermesidir. Dolayısıyla doğrudan atıf verileri eserin geçmiş performansı ve gelecekteki performansı ile bilgi vermesinin yanında ilişkide olduğu aktörleri belirlenmesini sağlamaktadır. $\mathrm{Bu}$ bağlamda scopus veri tabanından elde edilen bibliyometrik verilerden ikincisi, yayınların doğrudan atıf 
bilgileridir. Bu araştırmada yapılan atıf ağı analizinde, eserlerin sorumlu yazarlarına ait adres bilgileri baz alınarak kaynakçada yaptıkları atıfların hangi kaynak ülkeye ait olduğuna ilişkin bir analiz yapılmıştır. Yani veri tabanından elde edilen eserlerin atıf yaptı̆̆g eserlerin hangi ülke kökenli olduğuna dayalı bir analiz yapılmıştır. Bu sayede araştırma sahası için nitelikli eserler sunan ve katkı yapan ülkeler performans açısından belirlenmiştir. Ayrıca ortaya çıkan kümeler ile hangi ülkelerin bir arada atıf ilişkisinin olduğu görülmektedir. Araştırmalarda veri tabanından elde edilen 327 dokümanda 59 farklı ülkeden yayın bulunmaktadır. Ülkeler ölçeğinde en az 5 yayın yapmak ve 1 atıf almak varsayımı uygulandığında 24 ülke tespit edilmiştir. Bu ülkeler arasında atıf sayısı ve aralarında yaptıkları atıf ilişkisi en yüksek 22 ülke ağ haritasında yer almaktadır. Elde edilen sıklık ve aralarındaki atıf ilişkisi durumlarına ilişkin bulgular iki farklı boyutta analiz edilmiştir. Birincisi kümelenme boyutudur. $\mathrm{Bu}$ analize göre birbirleri arasında atıf ilişkisinin çok olduğu 7 küme tespit edilmiştir. Birinci kümede (kırmızı) Kanada, Japonya, Çin, İspanya ve İsviçre bulunmaktadır. Birinci küme grubunun en çok atıf yaptığı en yakın küme ise turuncu daireler ile temsil edilen yedinci kümedir. Bu kümenin odağında ABD olmakla birlikte ikinci elemanı İtalya'dır. Dolayısıyla birinci ve yedinci kümelerin atıf ilişkileri bakımından yakın olduğu söylenebilir. Bu gruba bir diğer yakın küme ise mavi renk ile temsil edilen üçüncü kümedir ve odağında Fransa bulunmaktadır. Diğer ülkeler ise Azerbaycan ve Hollanda'dır. İkinci küme (yeşil) odağında Almanya bulunmaktadır. Bu kümedeki diğer ilkeler Polonya ve Çek Cumhuriyeti'dir. İkinci kümenin en yakın atıf ilişkisinin olduğu mor renk ile temsil edilmekte olan beşinci kümedir ve merkezinde Rusya bulunmaktadır. Diğer ülkeler ise İngiltere ve Avusturya'dır. Bu gruba yakın diğer küme dördüncü kümedir (kahverengi) ve Türkiye, Ermenistan ve Yunanistan bulunmaktadır. Beşinci kümeye bir diğer yakın küme ise Gürcistan ve İran'ın bulunduğu altıncı kümedir (mavi). Bu sonuçlara göre atıf tercihleri ABD ve Rusya etrafında gruplanmıştır. Yapılan atıf analizine göre en çok yayın yapan ülkelerin en çok atıf alan çalışmalara sahip olduğu görülmektedir. Araştırma konusunun literatürdeki atıf kümelenmesine bakıldığında ise bölge ülkelerinin birbirlerine atıf yaptığ görülmektedir. Düşük iş birliği düzeyi ve yayın sayısına rağmen Kafkas ülkelerinin aynı atıf kümesi veya komşu atıf kümelerinde yer aldığı tespit edilmiştir. Bu durum bölge ülkelerinin literatürde birbirlerini takip ettiğini göstermektedir (Şekil 5 ve Çizelge 1). 


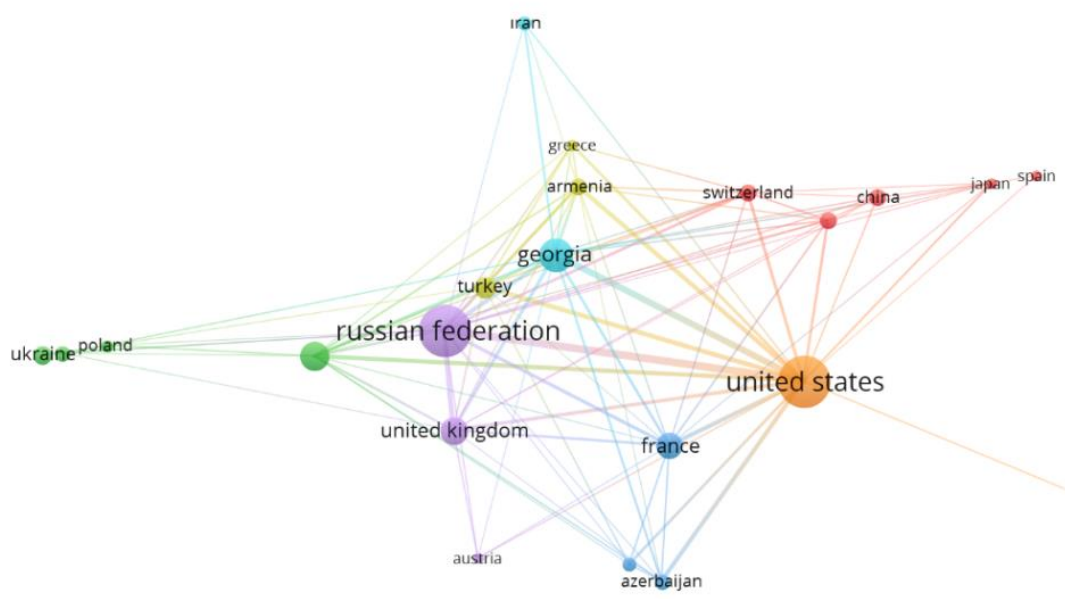

象 VOSviewer

Şekil 5. Ülkelere göre atıf ağı haritası

Çizelge 1. Ülkelere göre atıf analizi sonuçları

\begin{tabular}{|c|c|c|c|c|c|c|c|c|c|}
\hline Sira & Ülkeler & $\begin{array}{l}\text { Yayın } \\
\text { Sayısı* }\end{array}$ & $\begin{array}{l}\text { Alınan } \\
\text { Atıf ** }\end{array}$ & $\begin{array}{l}\text { Atıf Veren } \\
\text { Yayın } \\
\text { Sayısı*** }\end{array}$ & Sira & Ülkeler & $\begin{array}{l}\text { Yayın } \\
\text { Sayısi* }\end{array}$ & $\begin{array}{l}\text { Alınan } \\
\text { Atıf ** }\end{array}$ & $\begin{array}{l}\text { Atıf Veren } \\
\text { Yayın } \\
\text { Sayısı*** }\end{array}$ \\
\hline 1 & $\mathrm{ABD}$ (united states) & 98 & 5416 & 240 & 13 & İspanya (spain) & 5 & 161 & 2 \\
\hline 2 & Rusya Federasyonu (russian federation) & 95 & 2631 & 152 & 14 & Azerbaycan (azerbaijan) & 9 & 123 & 32 \\
\hline 3 & Türkiye (turkey) & 17 & 2238 & 57 & 15 & Japonya (japan) & 5 & 85 & 13 \\
\hline 4 & Gürcistan (georgia) & 40 & 1992 & 118 & 16 & $\begin{array}{l}\text { Çek Cumhuriyeti (czech } \\
\text { republic) }\end{array}$ & 9 & 79 & 8 \\
\hline 5 & Almanya (germany) & 30 & 1779 & 53 & 17 & Avusturya (austria) & 5 & 66 & 8 \\
\hline 6 & İsviçre (switzerland) & 10 & 1596 & 35 & 18 & Çin (china) & 11 & 47 & 11 \\
\hline 7 & Yunanistan (greece) & 5 & 1538 & 23 & 19 & İran (1ran) & 8 & 47 & 8 \\
\hline 8 & Ermenistan (armenia) & 10 & 1437 & 60 & 20 & Ukrayna (ukraine) & 12 & 41 & 3 \\
\hline 9 & Fransa (france) & 25 & 1406 & 58 & 21 & İsrail (1srael) & 6 & 40 & 0 \\
\hline 10 & Birleşik Kralık (united kingdom) & 28 & 765 & 67 & 22 & İtalya (1taly) & 6 & 32 & 2 \\
\hline 11 & Kanada (canada) & 10 & 254 & 26 & 23 & Polonya (poland) & 6 & 27 & 6 \\
\hline 12 & Hollanda (netherlands) & 8 & 202 & 16 & 24 & Sovyetler Birliği (ussr) $^{2}$ & 7 & 8 & 0 \\
\hline
\end{tabular}
oluşturmaktadir.

Elde edilen sıklık ve aralarında yaptıkları atıf ilişkisi durumlarına ilişkin bulgular iki farklı boyutta analiz edilmiştir. Analizin ikinci boyutu ise zaman trendidir. Yukarıda elde edilen kümelenme analizindeki varsayımlar geçerli olmak kaydıyla atıf örüntüsünün zaman trendi elde edilmiştir. Zaman trendi analizinde elde edilen en önemli sonuç ise yeni atıf odakları olarak Ukrayna, Polonya, Azerbaycan, Çin ve İran'ın tespit edilmesidir (Şekil 6). 


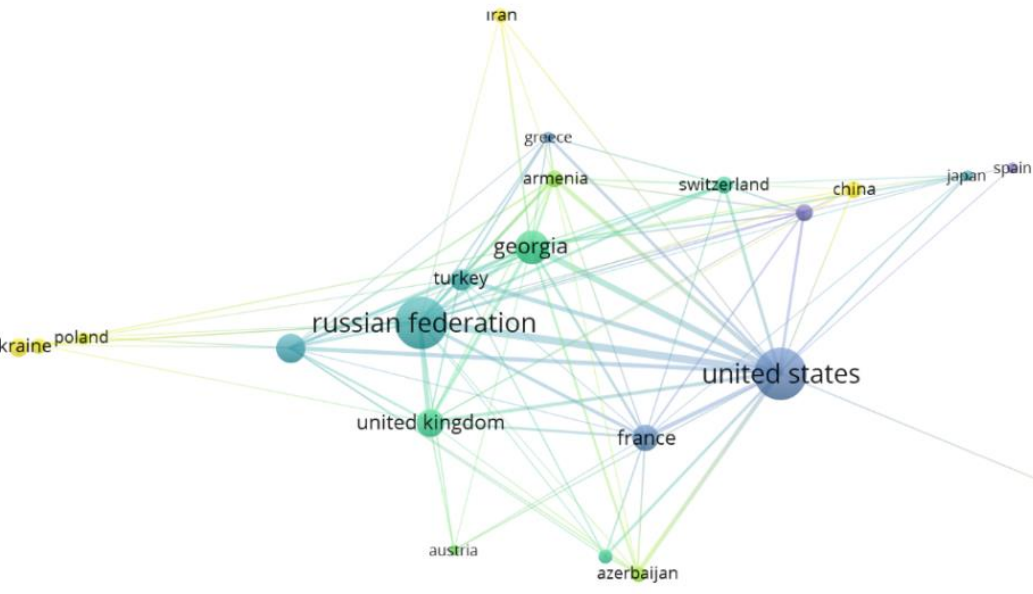

Şekil 6. Ülkelere göre atıf trendi

Bibliyometride kullanılan kurum, yazar vb. işbirliği çalışmalarının en önemli örneklerinden biri ortak yazarlı çalışmalardır (Glänzel ve Schubert, 2005). Ortak yazarlı çalışmalar modern bilimin yapısal değişimlerinin en iyi göstergesi niteliğindedir (Rodriguez ve Pepe, 2008). Aktörlerin üretkenliğine ait bir ağ çıkarılması planlandığında, ortak yazarlı çalışmalara ait istatistik ile yazarlar arası işbirliklerinin de ortaya konulması sağlanabilir. Bu örnekten yola çıkarak yapılacak bir haritalama çalışmasında, haritadaki yazarları veya ülkeleri simgeleyen dairelerin büyüklüğü, yazarın yayın sayısının; yazarlar arasındaki bağı oluşturan okların kalınlığı ise yazarlar veya ülkeler arasındaki ortak çalışmaların çokluğunu işaret etmektedir (Zan, 2012). Bu bağlamda bir bibliyografik yöntem olarak sosyal ağ analizi, ortak yazarlılık durumu ve kurumlar arası işbirliği gibi birbirine bağlı ağlar arasındaki ilişkilerin çıkarılması, bu ağ içerisinde ön plana çıkan aktörlerin (yazar, kurum, ülke vb.) ortaya çıkarılmasında oldukça önemli bir rol oynamaktadır (Metin, 2013). Scopus veri tabanından elde edilen bibliyometrik verilerden üçüncüsü, yazarlara ilişkin adres bilgileridir. Birinci yazarın ülkesi ve diğer yazarlara ilişkin ülke bilgileri, ortak yazarlılığına (co-authorship) göre analiz edilmiştir. Dolayısıyla hangi ülke araştırmacıların ortak çalışmalar içerisinde bulunduğu tespit edilmiştir. Araştırmalarda veri tabanından elde edilen 327 dokümanda 59 farklı ülkeden yayın bulunmaktadır. Ülkeler ölçeğinde en az 2 yayın yapmak varsayımı uygulandığında 37 ülke tespit edilmiştir. Bu ülkeler arasında görülme sıklığı ve ortak yazarlık (co-authorship) ilişkiselliği en yüksek 36 ülke ağ haritasında yer almaktadır. Elde edilen sıklık ve ortak yazarlık (co-authorship) durumlarına ilişskin bulgular iki farklı boyutta analiz edilmiştir. Birincisi kümelenme boyutudur. Eserlerde ortak yazarların hangi ülkeler arasında olduğu aşağıda 
görülmektedir. Buna göre 8 küme tespit edilmiştir. Birinci küme (kırmızı) odağında Fransa bulunmaktadır. İkinci küme (yeşil) odağında İsviçre bulunmaktadır. Üçüncü küme (mavi) odağında İngiltere, Almanya ve Gürcistan bulunmaktadır. Dördüncü küme (sarı) odağında Türkiye bulunmaktadır. Beşinci küme (mor) odağında $\mathrm{ABD}$ bulunmaktadır ve bu küme önceki dört kümenin de merkezinde yer alarak büyük bir küme grubunun liderliğini üstlenmiştir. Yani ilk beş kümenin birlikte iş yapma pratiklerinin daha fazla olduğu görülmektedir. Altıncı küme (turkuaz) merkezinde Rusya bulunmaktadır ve ağ haritasında diğer bloğu temsil etmektedir. Bu küme ile yakın iş birliği yapan Ermenistan ve Sırbistan'ın oluşturduğu yedinci kümedir. Sekizinci küme merkezinde Kanada bulunmaktadır ve beşinci küme ile yakın konumdadır (Şekil 7 ve Çizelge 2).

Ülkeler arası iş birliği analizinde diğer bulguları destekleyen bulgulara erişilmiştir. Buna göre araştırmacılar en çok ABD ve Rusya ile ortak çalışma yapmaktadır. ABD ile iş birliği yapan ülkeler farklı bölgelerde yer alırken, Rusya ile iş birliği yapan ülkelerin dağılımı daha homojendir. ABD'nin konum olarak bölgeye olan uzaklığı, farklı araştırmacılarla iş birliği kurmasını kolaylaştırmıştır. Ancak Rusya'nın Kafkas Dağlarında yer alması, daha çok bölgedeki diğer ülkelerle iş birliği yapmasına yol açmıştır. Yine bu ağ haritasına göre kıta Avrupası ülkeleri hem birbirleriyle hem de literatüre hakim olan ABD ve Rusya ile iş birliği yapmaktadır. Ancak örneğin aynı bölgede yer alan Türkiye ve Gürcistan birbirlerine iş birliği bağlamında daha uzak kümelerde yer almaktadır. Bir diğer örnek olarak ise Azerbaycan ve Ermenistan'ın birbirlerine zıt kümelerde yer alması, buna karşıllk en çok iş birliği yaptıkları ülkenin ise ABD olduğu görülmektedir. 


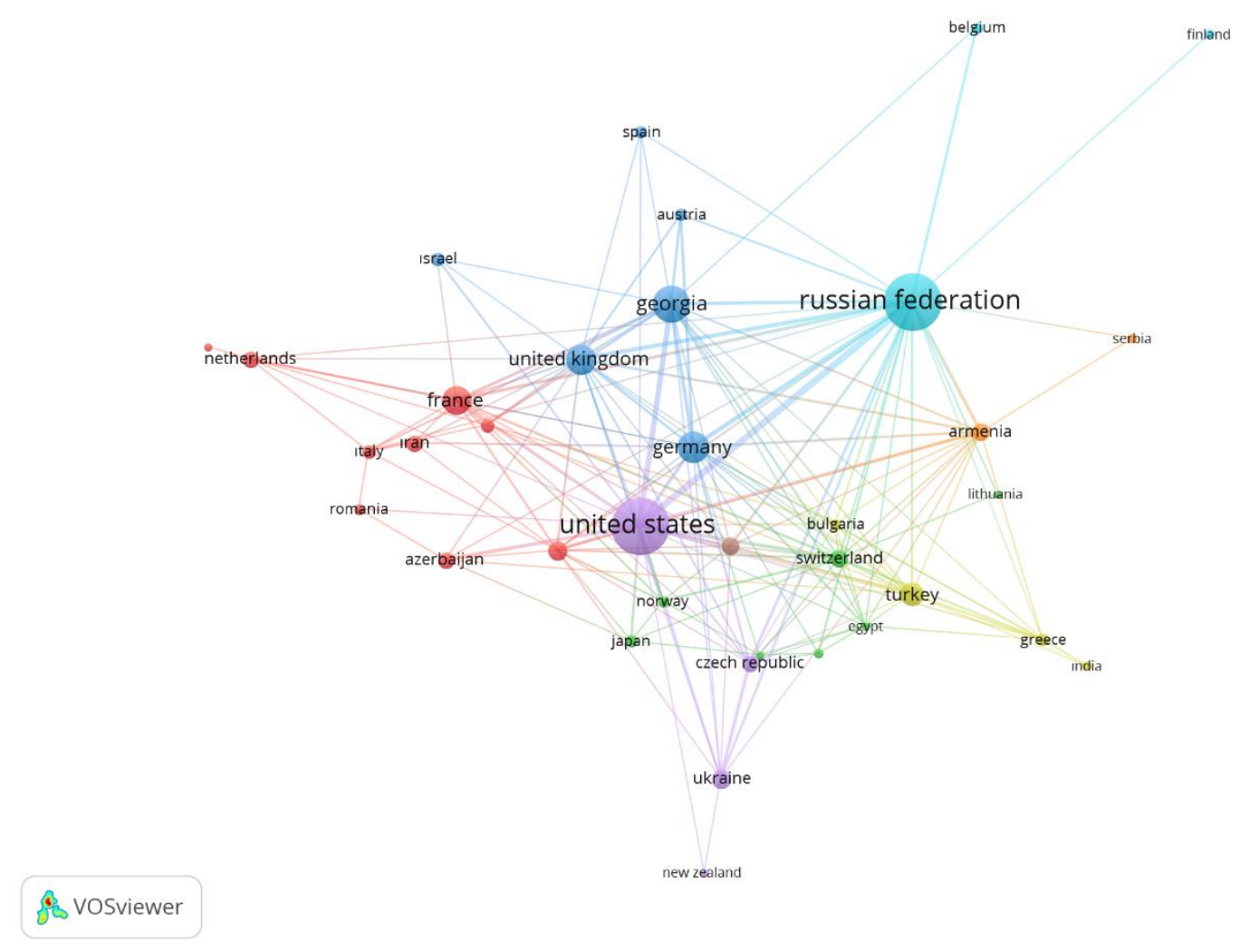

Şekil 7. Ülkeler arası ortak yazarlığa dayalı ağ haritası

Çizelge 2. Ülkeler arası ortak yazarlık analizi sonuçları

\begin{tabular}{|c|c|c|c|c|c|c|c|c|c|}
\hline Sira & Ülkeler & $\begin{array}{l}\text { Yayın } \\
\text { Sayısı* }\end{array}$ & $\begin{array}{l}\text { Alınan } \\
\text { Atıf:* }\end{array}$ & $\begin{array}{l}\text { Ortağı } \\
\text { Olduğu } \\
\text { Yayın } \\
\text { Sayısı*** }\end{array}$ & Sira & Ülkeler & $\begin{array}{l}\text { Yayın } \\
\text { Sayısı* }\end{array}$ & $\begin{array}{l}\text { Alınan } \\
\text { Attf** }\end{array}$ & $\begin{array}{l}\text { Ortağı } \\
\text { Olduğu } \\
\text { Yayın } \\
\text { Sayısı*** }\end{array}$ \\
\hline 1 & ABD (united states) & 98 & 5416 & 105 & 20 & Polonya (poland) & 6 & 27 & 11 \\
\hline 2 & Rusya Federasyonu (russian federation) & 95 & 2631 & 90 & 21 & Hollanda (netherlands) & 8 & 202 & 10 \\
\hline 3 & Gürcistan (georgia) & 40 & 1992 & 53 & 22 & İtalya (1taly) & 6 & 32 & 9 \\
\hline 4 & Almanya (germany) & 30 & 1779 & 48 & 23 & Japonya (japan) & 5 & 85 & 8 \\
\hline 5 & Birleşik Kralık (united kingdom) & 28 & 765 & 40 & 24 & Arjantin (argentina) & 2 & 5 & 7 \\
\hline 6 & Fransa (france) & 25 & 1406 & 32 & 25 & Slovakya (slovakia) & 3 & 23 & 6 \\
\hline 7 & Türkiye (turkey) & 17 & 2238 & 32 & 26 & İran (1ran) & 8 & 47 & 6 \\
\hline 8 & Ermenistan (armenia) & 10 & 1437 & 30 & 27 & İsrail (1srael) & 6 & 40 & 5 \\
\hline 9 & İsviçre (switzerland) & 10 & 1596 & 29 & 28 & Belçika (belgium) & 4 & 7 & 4 \\
\hline 10 & Çek Cumhuriyeti (czech republic) & 9 & 79 & 25 & 29 & İspanya (spain) & 5 & 161 & 4 \\
\hline 11 & Çin (china) & 11 & 47 & 24 & 30 & Romanya (romania) & 4 & 16 & 3 \\
\hline 12 & Ukrayna (ukraine) & 12 & 41 & 19 & 31 & Hindistan (1ndia) & 3 & 35 & 3 \\
\hline 13 & Bulgaristan (bulgaria) & 4 & 1393 & 15 & 32 & Litvanya (lithuania) & 2 & 4 & 2 \\
\hline 14 & Yunanistan (greece) & 5 & 1538 & 15 & 33 & Yeni Zellanda (new zealand) & 2 & 12 & 2 \\
\hline 15 & Kanada (canada) & 10 & 254 & 14 & 34 & Surbistan (serbia) & 3 & 12 & 2 \\
\hline 16 & Misır (egypt) & 2 & 1357 & 13 & 35 & Finlandiya (finland) & 3 & 6 & 1 \\
\hline 17 & Norveç (norway) & 4 & 44 & 13 & 36 & İsveç (sweden) & 2 & 8 & 1 \\
\hline 18 & Azerbaycan (azerbaijan) & 9 & 123 & 12 & 37 & Sovyetler Birliği (ussr) & 7 & 8 & 0 \\
\hline 19 & Avusturya (austria) & 5 & 66 & 11 & & & & & \\
\hline
\end{tabular}

*Şekil 6'daki dairelerin büyüklüğü, tablo 2'deki sorumlu yazarın bulunduğu ülkedeki yayın sayısı verisine göre değişmektedir.

** Tablo 2'deki sıralama alınan atıf verisine göre yapılmıștır.

*** Ortağı olduğu yayın sayısında, sorumlu yazar dışında farklı bir ülkede yer alan yazarlar olduğu varsayımına göre elde edilmektedir. Bu durum haritasındaki ağ (çizgi) dokusunu oluşturmaktadır.

Yazarların ülkelerine ilişkin elde edilen sıklık ve ortak yazarlık (co-authorship) durumlarına ilişkin bulgular iki farklı boyutta analiz edildiği daha önce belirtilmişti. Analizin ikinci boyutu ise zaman trendidir. Yukarıda elde edilen kümelenme analizindeki varsayımlar geçerli olmak kaydıyla ülkeler arası ortak yazarlıkta en çok görülen ilişkilerin zaman trendi elde edilmiştir. Zaman trendi analizinde elde 
edilen en önemli sonuçlar şunlardır: Yazarların ülkeler arası iş birliğine dayalı zaman trendinde yeni iş birliği eğilimleri incelendiğinde en önemli partnerlerin Ukrayna, İran, Romanya, Çin ve Belçika olduğu görülmektedir (Şekil 8).

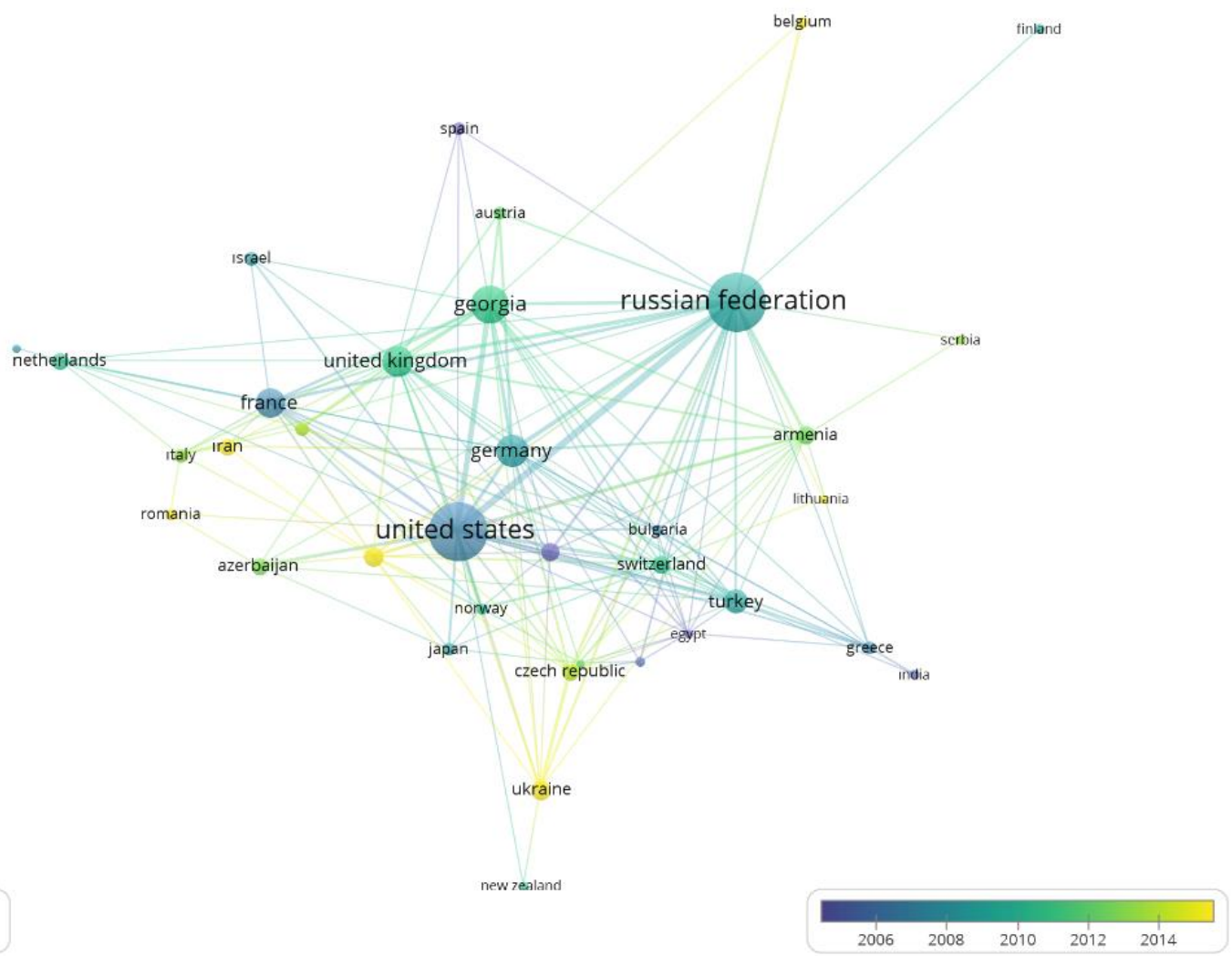

Şekil 8. Ülkeler arası ortak yazarlığa dayalı zaman trendi

Atıf analizi tekniklerinde en yaygın kullanılan tekniklerden bir tanesi de ortak atıf (co citiation) dır. Bir kaynakta farklı iki yayına atıf yapılması ortak atıf olarak tanımlanmaktadır (Al ve Tonta 2004: 23; Garfield 1988). Ortak atıf ağ haritası: bu harita birbirinden bağımsız çalışmaların hangi eserler üzerinde yoğunlaştığını göstermektedir. Bu bağlamda öne çıkan isimler Kafkas Dağları araştırmalarının odağında yer alan isimlerdir. Elde edilen harita bazı varsayımlar sonucu elde edilmiştir. Eserlerin kaynakçasında yer alan 17. 863 yazar içerisinde en az 20 atıf alan 61 yazar tespit edilmiştir ve haritaya yansımıştır. Analizde 6 küme tespit edilmiştir. Fakat kümeler 3 farklı grup oluşturduğu görülmektedir. Kafkas Dağları alanında en çok atıf yapılan araştırmacıların Jeoloji ve tektonik konularında çalışanlar olduğu, buna ek olarak diğer bulgularla uyumlu olarak ABD'li oldukları tespit edilmiştir. Dolayısıyla atıf ağının ortasında bu küme yer almaktadır (Şekil 9 ve Çizelge 3). 


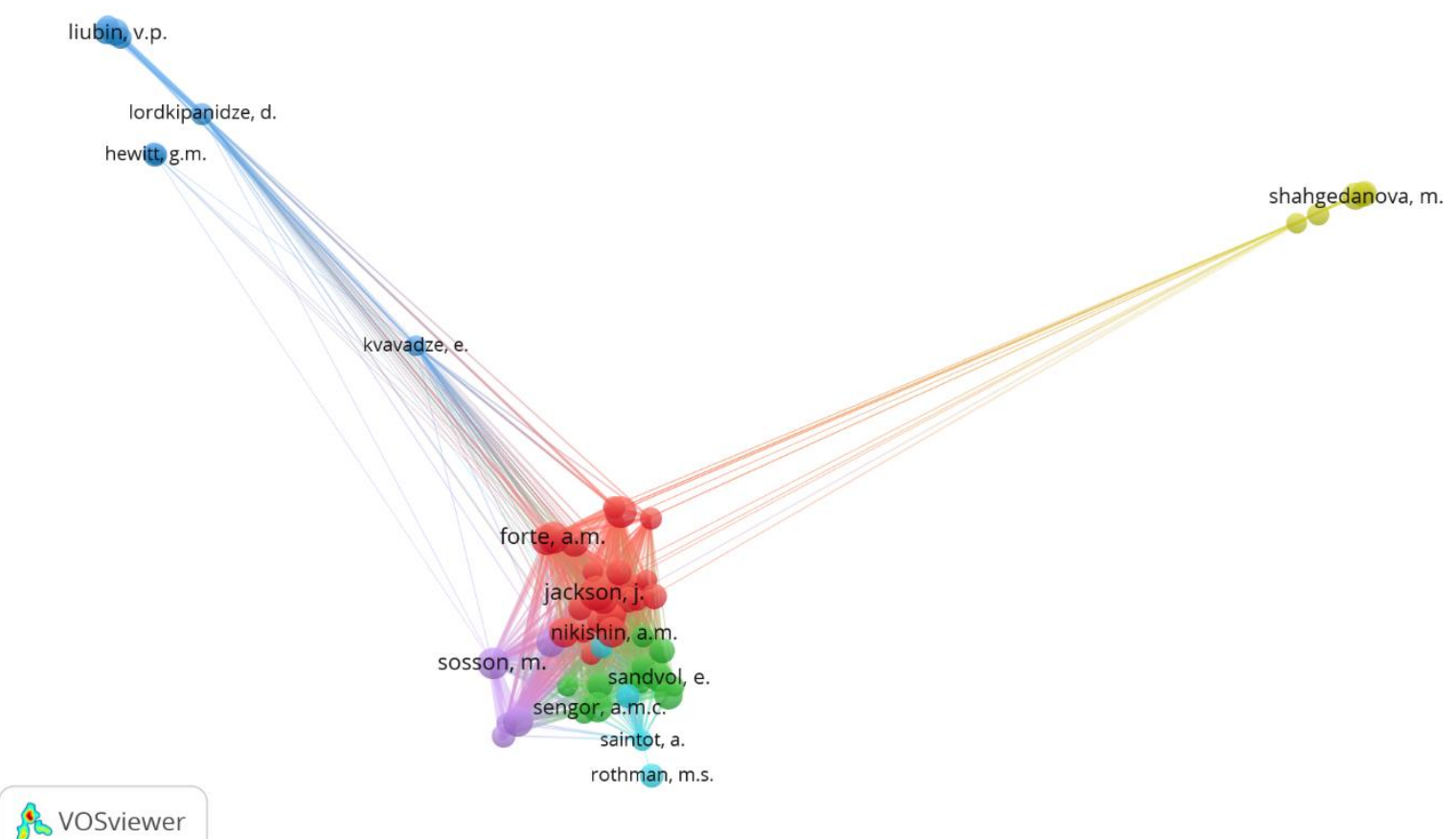

Şekil 9. Ortak atıf ağ haritası

Çizelge 3. En çok ortak atıf alan yazarlar

\begin{tabular}{|c|c|c|c|c|c|}
\hline Sira & Birinci Yazar & Atıf & İlişkisellik & Ülke ve Kurum & Alan \\
\hline 1 & jackson, j. & 58 & 3235 & İngiltere/University of Cambridge & Tektonik \\
\hline 2 & forte, a.m. & 51 & 3384 & ABD/Louisiana State University & Jeoloji \\
\hline 3 & whipple, k.x. & 51 & 2831 & $\mathrm{ABD} /$ Arizona State University & Drenaj Deformasyon \\
\hline 4 & sosson, m. & 48 & 4514 & Fransa/Universite'Co^te d'Azur & Tektonik \\
\hline 5 & sengor, a.m.c. & 44 & 2875 & ITU/Eurasia Institute of Earth Sciences & Tektonik \\
\hline 6 & allen, m.b. & 43 & 2997 & İngiltere/Durham University & İklim Değişikliği, Tektonik \\
\hline 7 & cowgill, e. & 43 & 2950 & $\mathrm{ABD} /$ University of California & Jeoloji \\
\hline 8 & nikishin, a.m. & 43 & 2632 & Moscow State University & Tektonik, Jeoloji \\
\hline 9 & rolland, y. & 43 & 4133 & $*$ & * \\
\hline 10 & callaway, r.m. & 41 & 0 & ABD/University of Montana & Doğa Bilimleri \\
\hline 11 & adamia, s. & 40 & 3203 & Gürcistan/Tbilisi State University & Tektonik \\
\hline 12 & barazangi, m. & 40 & 1914 & ABD/Cornell University & Tektonik, Jeoloji \\
\hline 13 & reilinger, $\mathrm{r}$. & 40 & 2134 & $\mathrm{ABD} / \mathrm{MIT}$ & Tektonik \\
\hline 14 & sandvol, e. & 39 & 2273 & ABD/University of Missouri & Tektonik \\
\hline 15 & brunet, m.-f. & 38 & 2325 & Fransa/Sorbonne University & Jeoloji \\
\hline 16 & philip, h. & 38 & 2012 & Fransa/ Montpellier University & Jeoloji \\
\hline 17 & liubin, v.p. & 35 & 1060 & $*$ & Paleolitik \\
\hline 18 & shahgedanova, $\mathrm{m}$. & 35 & 392 & İngiltere/ University of Reading & İklim Değişikliği \\
\hline 19 & baryshnikov, g.f. & 33 & 455 & Rusya/Russian Academy of Sciences & Zooloji \\
\hline 20 & cisternas, a. & 33 & 1505 & Şili/ University of Chile & Jeofizik \\
\hline & & & & Türkiye/Boğaziçi University Kandilli Observatory and & \\
\hline 21 & turkelli, n. & 33 & 2077 & Earthquake Research Institute & Tektonik, Jeofizik \\
\hline 22 & kaab, a. & 32 & 279 & Norveç/Oslo University & Yerbilimleri \\
\hline 23 & cloetingh, s. & 31 & 1148 & Hollanda/Utrecht University & Jeoloji \\
\hline 24 & ershov, a.v. & 31 & 1935 & Rusya/Lomonosov Moscow State University & Jeoloji \\
\hline 25 & priestley, $\mathrm{k}$. & 31 & 1742 & İngiltere/University of Cambridge & Jeofizik Jeodinamik Tektonik \\
\hline 26 & hewitt, g.m. & 29 & 60 & İngiltere/University of East Anglia & Evrimsel Genetik Glasyal \\
\hline 27 & vincent, s.j. & 29 & 2123 & İngiltere/University of Cambridge & Jeoloji, Tektonik \\
\hline 28 & zor, e. & 29 & 1711 & Türkiye/TUBITAK & Jeofizik \\
\hline 29 & angelier, $\mathrm{j}$. & 27 & 678 & Fransa/French National Centre for Scientific Research & Tektonik \\
\hline 30 & galoyan, g. & 27 & 2792 & Ermenistan/Institute of Geological Sciences & Jeoloji \\
\hline 31 & rothman, m.s. & 27 & 5 & ABD/University of Pennsylvania & Antropoloji \\
\hline 32 & keskin, $\mathrm{m}$. & 26 & 1687 & Türkiye/İstanbul University & Jeoloji \\
\hline 33 & willett, s.d. & 26 & 1480 & İsviçre/ETH Zurich & Jeoloji, Tektonik \\
\hline 34 & bolotov, s.n. & 25 & 1357 & Rusya/GEOGRID & Jeoloji \\
\hline 35 & gok, r. & 25 & 1641 & ABD/ Lawrence Livermore National Laboratory & Jeofizik \\
\hline 36 & haeberli, w. & 25 & 349 & İsviçre/University of Zurich & İklim Değişikliği \\
\hline
\end{tabular}




\begin{tabular}{|c|c|c|c|c|c|}
\hline 37 & lordkipanidze, d. & 25 & 1135 & Gürcistan/University of Georgia & Antropolji, Arkeoloji \\
\hline 38 & mcclusky, s. & 25 & 1381 & Avustralya/Australian National University & Tektonik \\
\hline 39 & beaumont, c. & 24 & 1536 & Kanada/Dalhouise University & Oşinografi \\
\hline 40 & korotaev, m.v. & 24 & 1479 & Rusya/Moscow State University & Jeoloji \\
\hline 41 & popovnin, v.v.** & 24 & 349 & Rusya/Lomonosov Moscow State University & Jeoloji \\
\hline 42 & tushabramishvili, $\mathrm{n}$. & 24 & 911 & Gürcistan/Ilia State University & Arkeoloji \\
\hline 43 & golovanova, l.v. & 23 & 710 & Rusya/ ANO Laboratory of Prehistory & Arkeoloji \\
\hline 44 & molnar, p. & 23 & 1276 & ABD/Colorado University & Jeoloji \\
\hline 45 & stokes, c.r. & 23 & 421 & İngiltere/Durham University & Coğrafya \\
\hline 46 & braasch, $\mathrm{d}$. & 22 & 3 & Almanya/* & Entomoloji \\
\hline 47 & paul, f. & 22 & 376 & İsviçre/University of Zurich & Fiziki Coğrafya \\
\hline 48 & saintot, a. & 22 & 975 & Almanya/Ruhr University Bochum & GIS, Jeoloji \\
\hline 49 & seber, d. & 22 & 1205 & ABD/Cornell University & Jeoloji \\
\hline 50 & taberlet, p. & 22 & 50 & Fransa/ Université Joseph Fourier & Jeoloji \\
\hline 51 & avagyan, a. & 21 & 2296 & Ermenistan/Institute of Geological Sciences & Jeoloji \\
\hline 52 & kidd, w.s.f. & 21 & 963 & İngiltere/University of Cambridge & Jeoloji \\
\hline 53 & saroglu, f. & 21 & 1013 & Türkiye/JEMIRKO & Jeoloji \\
\hline 54 & taylor h.p. & 21 & 70 & $\mathrm{ABD} /$ California Institute of Technology & Jeoloji \\
\hline 55 & gamkrelidze, 1.p. & 20 & 923 & Gürcistan/ Ivane Javakhishvili Tbilisi State University & Jeoloji \\
\hline 56 & gorshkov, a. & 20 & 848 & Rusya/Russian Academy of Science & Jeofizik \\
\hline 57 & gurbanov, a.g. & 20 & 711 & Rusya/Russian Academy of Science & Jeoloji \\
\hline 58 & kuemmerle, t. & 20 & 0 & Almanya/Humboldt University zu Berlin & Coğrafya \\
\hline 59 & kvavadze, e. & 20 & 499 & Gürcistan/ Georgian National Academy of Sciences & Biyoloji \\
\hline 60 & mckenzie, d. & 20 & 894 & İngiltere/University of Cambridge & Jeofizik \\
\hline 61 & niemi, n.a. & 20 & 1586 & $\mathrm{ABD} /$ University of Michigan & Jeoloji \\
\hline 62 & popovnin, v.** & 20 & 318 & Rusya/Lomonosov Moscow State University & Jeoloji \\
\hline 63 & zonenshain, 1.p. & 20 & 1058 & Rusya/Russian Academy of Sciences & Jeoloji \\
\hline
\end{tabular}

\subsection{Kafkas Dağları Araştırmalarında Mevcut ve Yeni Kavramlar}

Araştırma Kafkas Dağları olgusunun literatürdeki evrimini incelemektedir. Dolayısıyla araştırma sonuçları araştırma olgusunun gelecek durumu ile ilgili bir tahmin yapacaktır. Bu bağlamda araştırmanın ikinci boyutu araştırma sahası ölçeğinde araştırılan terimlerin tespiti olmuştur. Bu aşamada yapılan analizler şunlardır: Özet ve başlık bölümünde kullanılan kavramların ağ analizi ve anahtar kelimeler bölümünde kullanılan kavramların ağ analizi. Dolayısıyla bu analizler sayesinde olgu hakkında yapılan araştırmalarda geçmiş, mevcut ve gelecek araştırma konularına ilişkin tespitler yapılmıştır.

Scopus veri tabanından elde edilen özet ve başlıkta yer alan metinsel veriler birlikte kullanımlarına (co-occurance) göre analiz edilmiştir. Araştırmalarda terimsel değer taşıyan kelimelerin tespiti için 327 dokümanın başlık ve özet bölünde kullanılan 10.806 kelime içerisinde en az 7 kez tekrarlanmış 206 terim bulunmuştur. Bu analizde terimler arasında görülme sıklığı ve birlikte bulunma (co-occurance), yani ilişkiselliği en yüksek 124 terim ağ haritasında yer almaktadır. Elde edilen sıklık ve birlikte kullanılma durumlarına ilişsin bulgular iki farklı boyutta analiz edilmiştir. Birincisi kümelenme boyutudur. Bu analizden çıkan en önemli sonuçlar şunlardır: 4 terim kümesi oluşmuştur. Birinci küme, kırmızı ile gösterilen daha çok biyoloji ve doğal çevre çalışmalarını içermektedir. İlişkiselliğin ve sıklığın en yüksek olduğu kavramlar gen akışı, popülasyon, köken vb. İkinci küme yeşil ile gösterilmektedir ve jeoloji ve jeomorfoloji çalışmalarının ağılıkta olduğu görülmektedir. İlişkiselliğin ve sıklığın en yüksek olduğu kavramlar deformasyon, zone, sediment, gözlem vb. üçüncü küme mavi ile gösterilmektedir ve ekoloji çalışmalarından oluşmaktadır. Özellikle ağırlık kazanan konular iklim değişikliği, orman ve toprak varlıkları olmuştur. Dördüncü küme sarı ile gösterilmekte ve birinci ve üçüncü küme arasında geçiş kümesi olarak yer almaktadır. Kırmızı, mavi ve sarı kümeler aralarında ilişkisellik ve ortak terim kullarını yüksek iken, yeşil küme diğer araştırma kümelerinden belirgin bir şekilde ayrışmaktadır. Bu alanda özellikle sosyal bilimlere ilişkin kavramların az olması 
Kafkas dağları olgusunun sosyal boyutu ile ele alan çalışmaların az olduğunu göstermektedir (Şekil 10 ve Çizelge 4).

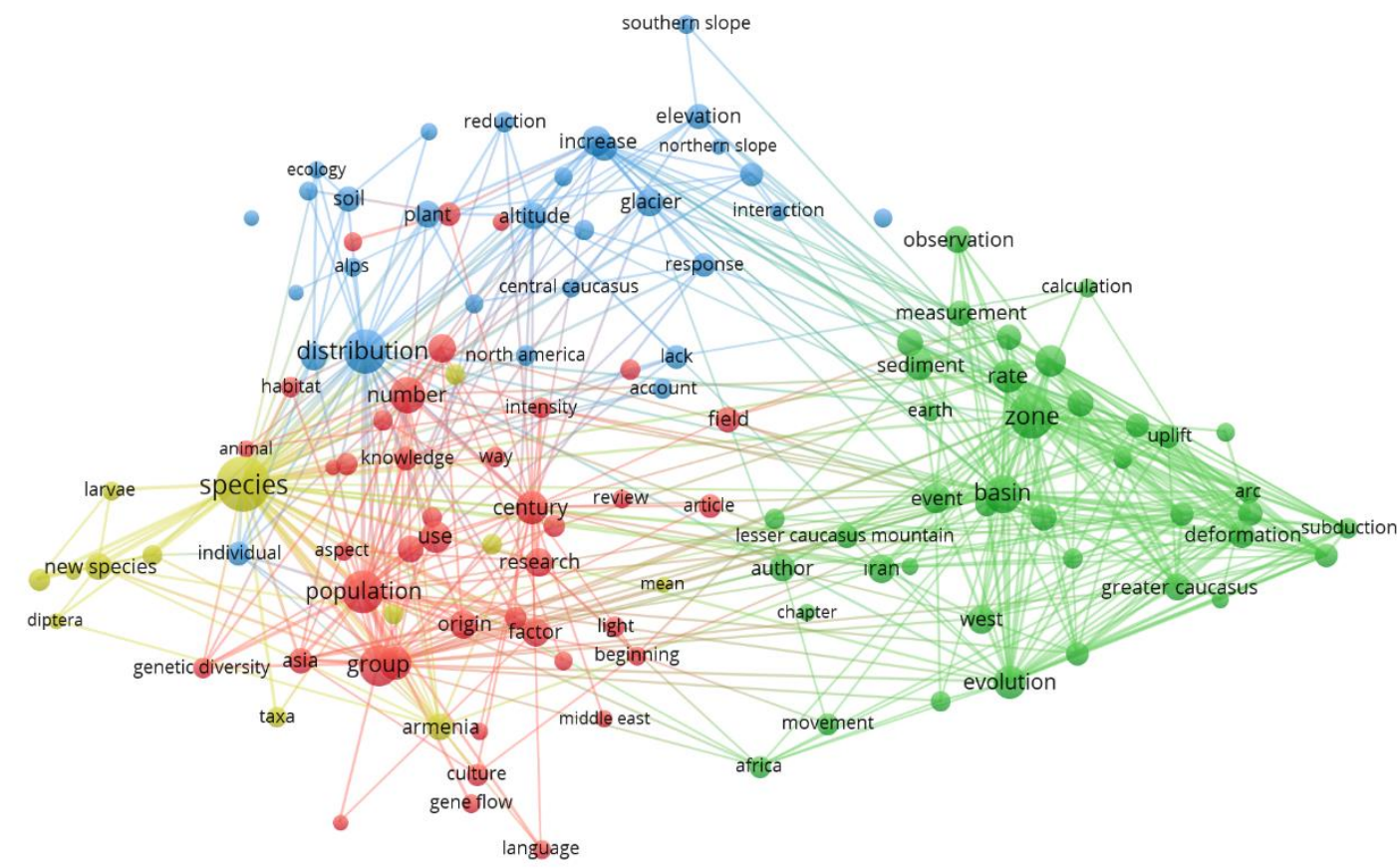

\& VOSviewer

Şekil 10. Özet ve başlıklarda en çok kullanılan terimlerin ağ analizi

Çizelge 4. Özet ve başlıklarda en çok kullanılan terimlerin istatistiksel sonuçları

\begin{tabular}{|c|c|c|c|c|c|c|c|}
\hline \multirow[b]{2}{*}{ Sira } & \multirow[b]{2}{*}{ Terim } & \multicolumn{3}{|c|}{ İlişkisellik } & \multirow[b]{2}{*}{ Terim } & \multicolumn{2}{|c|}{ İlişkisellik } \\
\hline & & Sıklık* & Skoru & Sira & & Sıklık* & Skoru \\
\hline 1 & Türler (species) & 76 & 11.166 & 63 & Dağ Eteği (foothill) & 13 & 0.7309 \\
\hline 2 & Zon (zone) & 54 & 0.898 & 64 & Önem (importance) & 13 & 0.7136 \\
\hline 3 & Dağılıș (distribution) & 49 & 0.5495 & 65 & Hareket (movement) & 13 & 0.3276 \\
\hline 4 & Nüfus (population) & 47 & 0.7337 & 66 & Kasım (nov) & 13 & 42.573 \\
\hline 5 & Grup (group) & 43 & 0.5169 & 67 & Anadolu (anatolia) & 12 & 0.8961 \\
\hline 6 & Havza (basin) & 38 & 0.7731 & 68 & Gün (day) & 12 & 0.6366 \\
\hline 7 & Numara (number) & 33 & 0.4823 & 69 & Habitat (habitat) & 12 & 11.233 \\
\hline 8 & Asir (century) & 29 & 0.5607 & 70 & Yoğunluk (intensity) & 12 & 0.4233 \\
\hline 9 & Oran (rate) & 29 & 0.7938 & 71 & Yerellik (locality) & 12 & 10.202 \\
\hline 10 & İlişki (relationship) & 29 & 0.5844 & 72 & Kuzey Amerika (north america) & 12 & 0.4384 \\
\hline 11 & Evrim (evolution) & 28 & 0.729 & 73 & Kişi (person) & 12 & 0.7124 \\
\hline 12 & $\begin{array}{l}\text { Büyük Kafkas Dağları (greater caucasus } \\
\text { mountain) }\end{array}$ & 25 & 10.016 & 74 & Dizi (series) & 12 & 0.5096 \\
\hline 13 & Kullanım (use) & 25 & 0.6692 & 75 & Evre (stage) & 12 & 0.4112 \\
\hline 14 & Olay (event) & 24 & 0.7938 & 76 & Yol (way) & 12 & 0.5447 \\
\hline 15 & Artıș (increase) & 23 & 0.6152 & 77 & Hesap (account) & 11 & 0.3376 \\
\hline 16 & Sediment (sediment) & 23 & 0.7964 & 78 & Detay (detail) & 11 & 0.5821 \\
\hline 17 & Köken (origin) & 22 & 0.454 & 79 & İlk Defa (first time) & 11 & 0.7315 \\
\hline 18 & Bat1 (west) & 22 & 0.736 & 80 & Genetik Çeşitlilik (genetic diversity) & 11 & 15.559 \\
\hline 19 & İran (Iran) & 22 & 0.2213 & 81 & Tür (genus) & 11 & 19.456 \\
\hline 20 & Faktör (factor) & 21 & 0.5114 & 82 & İnsan (human) & 11 & 0.937 \\
\hline 21 & Glasyer (glacier) & 21 & 0.626 & 83 & Işık (light) & 11 & 0.8849 \\
\hline 22 & Araştırma (research) & 20 & 0.7127 & 84 & Azaltma (reduction) & 11 & 0.7001 \\
\hline 23 & Dünya (world) & 20 & 0.6961 & 85 & Subdüksiyon (subduction) & 11 & 28.141 \\
\hline 24 & Ermenistan (armenia) & 19 & 0.568 & 86 & Taksonlar (taxa) & 11 & 11.428 \\
\hline 25 & Derinlik (depth) & 19 & 10.316 & 87 & Toplam (total) & 11 & 0.3611 \\
\hline 26 & Orman (forest) & 19 & 10.171 & 88 & Alpler (alps) & 10 & 0.6705 \\
\hline
\end{tabular}




\begin{tabular}{|c|c|c|c|c|c|c|c|}
\hline 27 & Formasyon (formation) & 19 & 11.556 & 89 & Bak1 (aspect) & 10 & 0.9343 \\
\hline 28 & Büyük Kafkaslar (greater caucasus) & 19 & 16.146 & 90 & Başlangıç (beginning) & 10 & 0.3607 \\
\hline 29 & Yeni Türler (new species) & 19 & 32.767 & 91 & Merkez Kafkaslar (central caucasus) & 10 & 0.7804 \\
\hline 30 & Gözlem (observation) & 19 & 0.7008 & 92 & Büyük (greater) & 10 & 10.312 \\
\hline 31 & Bitki (plant) & 19 & 10.393 & 93 & Etkileşim (interaction) & 10 & 0.5375 \\
\hline 32 & Rakım (altitude) & 18 & 0.5716 & 94 & Değerlendirme (review) & 10 & 0.3515 \\
\hline 33 & Yazar (author) & 18 & 0.439 & 95 & Güney Rusya (southern russia) & 10 & 0.4812 \\
\hline 34 & İklim (climate) & 18 & 0.5136 & 96 & Kış (winter) & 10 & 14.871 \\
\hline 35 & Ülke (country) & 18 & 0.8319 & 97 & Hesaplama (calculation) & 9 & 14.143 \\
\hline 36 & Deformasyon (deformation) & 18 & 22.861 & 98 & Merkez Asya (central asia) & 9 & 0.3952 \\
\hline 37 & Mekanizm (mechanism) & 18 & 0.4454 & 99 & Dünya (earth) & 9 & 0.7858 \\
\hline 38 & Asya (asia) & 17 & 0.8641 & 100 & Deprem (earthquake) & 9 & 2.013 \\
\hline 39 & Bileșken (component) & 16 & 0.7258 & 101 & Doğu bölüm (eastern part) & 9 & 0.3015 \\
\hline 40 & Yükseklik (elevation) & 16 & 0.3359 & 102 & Gen Akımı (gene flow) & 9 & 0.9043 \\
\hline 41 & Fay (fault) & 16 & 24.165 & 103 & Dil (language) & 9 & 13.271 \\
\hline 42 & Alan (field) & 16 & 0.462 & 104 & Larva (larvae) & 9 & 29.106 \\
\hline 43 & Ölçüm (measurement) & 16 & 0.8139 & 105 & Bitki Topluluğu (plant community) & 9 & 11.026 \\
\hline 44 & Toprak (soil) & 16 & 12.189 & 106 & Güney Eğim (southern slope) & 9 & 0.7646 \\
\hline 45 & Bilgi (knowledge) & 15 & 0.8894 & 107 & Bahar (spring) & 9 & 11.734 \\
\hline 46 & Küçük Kafkaslar (lesser caucasus) & 15 & 11.209 & 108 & Hayvan (animal) & 8 & 12.875 \\
\hline 47 & Güney (south) & 15 & 0.8025 & 109 & Bölüm (chapter) & 8 & 0.3895 \\
\hline 48 & Canlandırma (uplift) & 15 & 17.078 & 110 & Karşıt (contrast) & 8 & 0.5354 \\
\hline 49 & Sürat (velocity) & 15 & 13.227 & 111 & Ekoloji (ecology) & 8 & 16.015 \\
\hline 50 & Makale (article) & 14 & 0.4805 & 112 & Kuruluş (establishment) & 8 & 12.375 \\
\hline 51 & $\begin{array}{l}\text { Merkez Kafkas Dağları (central caucasus } \\
\text { mountain) }\end{array}$ & 14 & 0.6336 & 113 & İnsan (man) & 8 & 10.893 \\
\hline 52 & Kıta Çarpıșması (collision) & 14 & 28.012 & 114 & Orta Doğu (middle east) & 8 & 0.8696 \\
\hline 53 & Avrasya (eurasia) & 14 & 11.521 & 115 & Miyosen (miocene) & 8 & 17.227 \\
\hline 54 & Bireysel (individual) & 14 & 1.105 & 116 & Sovyetler Birliği (ussr) & 8 & 12.615 \\
\hline 55 & Eksik (lack) & 14 & 0.1681 & 117 & Yetişkin (adult) & 7 & 3.816 \\
\hline 56 & $\begin{array}{l}\text { Küçük Kafkas Dağları (lesser caucasus } \\
\text { mountain) }\end{array}$ & 14 & 0.2482 & 118 & $\begin{array}{l}\text { Kafkas Dağlık Alanı (caucasus mountain } \\
\text { region) }\end{array}$ & 7 & 17.882 \\
\hline 57 & Sorumluluk (response) & 14 & 0.2867 & 119 & Çiftekanatlılar (diptera) & 7 & 38.451 \\
\hline 58 & Yaz (summer) & 14 & 10.199 & 120 & Belirleme (identification) & 7 & 10.534 \\
\hline 59 & Afrika (africa) & 13 & 0.3963 & 121 & Ortalama ()mean & 7 & 0.3119 \\
\hline 60 & Kemer $(\operatorname{arc})$ & 13 & 21.001 & 122 & Kuzey Eğim (northern slope) & 7 & 0.4054 \\
\hline 61 & $\begin{array}{l}\text { Kafkas Dağları Silsilesi (caucasus mountain } \\
\text { range) }\end{array}$ & 13 & 0.4405 & 123 & $\begin{array}{l}\text { Vejetasyon (vegetation) } \\
\text { Batı Kafkas Dağları (western caucasus }\end{array}$ & 7 & 10.677 \\
\hline 62 & Kültür (culture) & 13 & 12.222 & 124 & mountain) & 7 & 14.557 \\
\hline
\end{tabular}

$62 \quad$ Kültür (culture)

*Şekil 10'daki dairelerin büyüklüğü, tablo 4'deki yayınlarda bulunan terimlerin sıklık verisine göre değişmektedir. Ayrıca Tablo 4'deki sıralama terimlerin sıklık verisine göre yapılmıştır.

** İlişkisellik skoru, terimlerin birbirleri ile kullanım sıklığına belirlenen bir istatistiktir. Bu durum haritasındaki ağ (çizgi) dokusunu oluşturmaktadır. İlişkisellik skoru terimlerin birbiri ile kullanım sıklığı arttıkça kümeleri de oluşturmaktadır. Bu durum haritasındaki küme dokusunu olușturmaktadır.

Elde edilen sıklık ve birlikte kullanılma durumlarına ilişkin bulgular iki farklı boyutta analiz edilmiştir. Analizin ikinci boyutu ise zaman trendidir. Yukarıda elde edilen kümelenme analizindeki varsayımlar geçerli olmak kaydıyla özet ve başlıkta en çok kullanılan terimlerin zaman trendi elde edilmiştir. Zaman trendi analizinde elde edilen en önemli sonuçlar şunlardır: Özellikle yeni çalışmaların ekoloji alanda yoğunlaştığı söylenebilir. Bu bağlamda öne çıkan yeni terimlerin yoğunluk, yeni türler, Asya, gen akışı, genetik çeşitlilik, Ermenistan, habitat ve köken olduğu tespit edilmiştir. Jeoloji ve jeomorfoloji çalışmalarının ise daha geleneksel bir konumda olduğu söylenebilir (Şekil 11). 


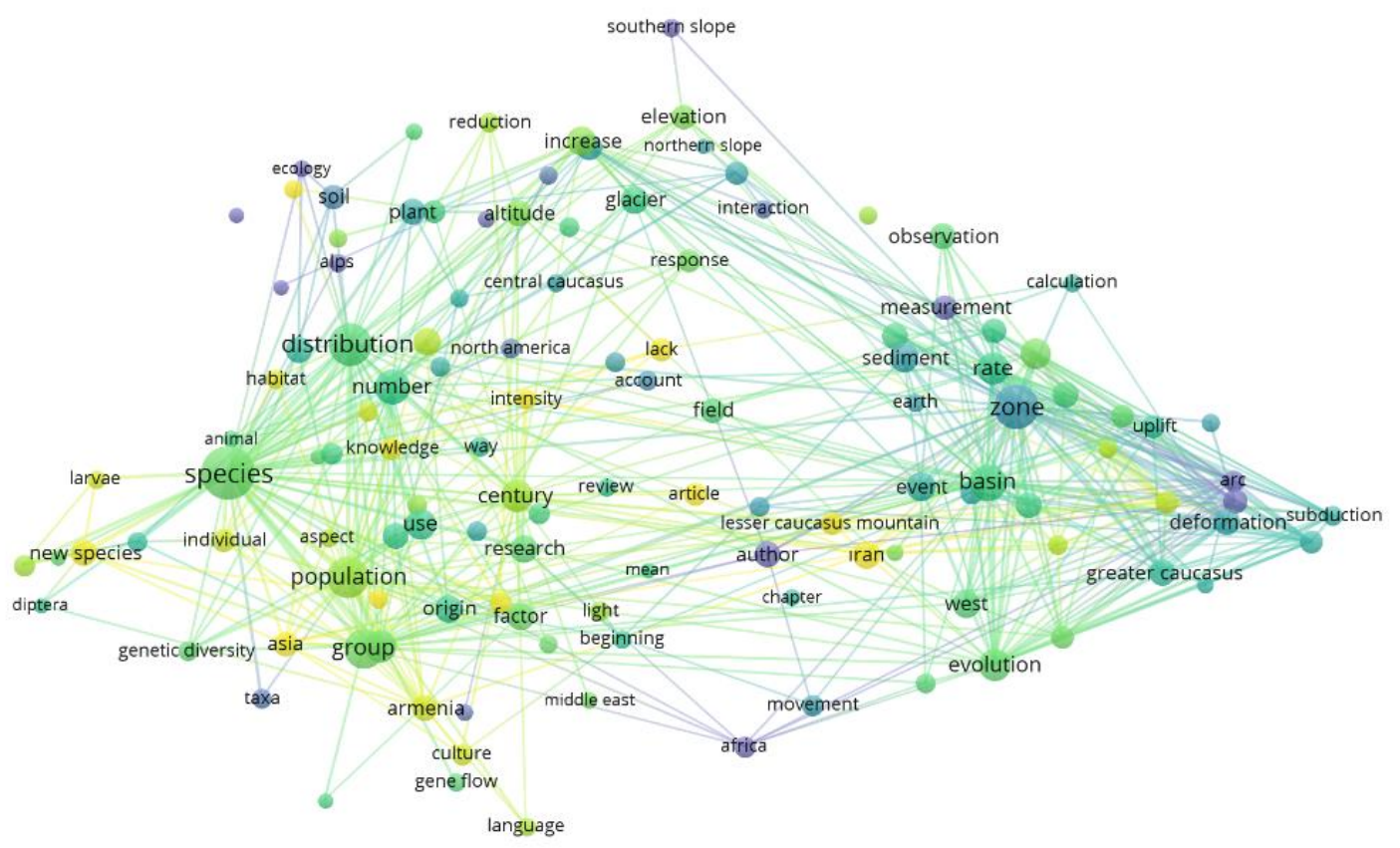

\& vosviewer

Şekil 11. Özet ve başlıklarda en çok kullanılan terimlerin zaman trendi

Scopus veri tabanından elde edilen bibliyometrik verilerden birincisi olan anahtar kelimeler birlikte kullanımlarına (co-occurance) göre analiz edilmiştir. Araştırmalarda veri tabanından elde edilen 327 dokümanın anahtar kelimeler bölümünde kullanılan 812 terim içerisinde en az 2 kez tekrarlanmış 72 terim tespit edilmiştir. $\mathrm{Bu}$ analizde terimler arasında görülme sıklığı ve birlikte bulunma (cooccurance), yani ilişkiselliği en yüksek 64 terim ağ haritasında yer almaktadır. Elde edilen sıklık ve birlikte kullanılma durumlarına ilişkin bulgular iki farklı boyutta analiz edilmiştir. Birincisi kümelenme boyutudur. Buna göre 12 küme tespit edilmiştir. Birinci küme kırmızı ile gösterilmiş ve mekânsal olarak daha çok Alpler ve Türkiye'de konumlanmıştır. Alansal olarak ise biyocoğrafya çalışmaları önde görülmektedir. Aynı şekilde 11. küme (açık yeşil) birinci kümenin devamı niteliğindedir. İkinci küme yeşil ile gösterilmiş ve alansal ağılık biyoloji olarak görülmektedir. Üçüncü küme (mavi) ve on ikinci küme (açık mavi) ise biyocoğrafya ve biyoloji araştırmaları arasında ortak olarak kullanılan terimlerden oluşmaktadır. Yani birinci ve ikinci kümeler arasında ortak terimleri içermektedir. Dördüncü küme sarı ile gösterilmiş daha çok mekânsal ağrılık Rusya ve denizler üzerinde görülmektedir. Beşinci küme (mor) ilişkisellik bakımından en önemli konumdadır. $\mathrm{Bu}$ küme genellikle iklim araştırmalarından oluşmaktadır. Pembe olarak temsil edilen dokuzuncu küme ise yine iklim araştırmalarına bağlı gelişen bir terim topluluğudur. Altıncı küme turkuaz ile gösterilmiş ve mekânsal olarak Abhazya'ya ait sosyal bilim çalışmaları görülmektedir. Bunlar arasından etnisite, göç ve Hristiyanlık üzerine yoğunlaşılmıştır. Açık pembe olarak temsil edilen 10. küme ise yine iklim araştırmalarına bağlı gelişen vejetasyon 
araştırmalarına ilişkin terim topluluğudur. Yedi ve sekizinci kümeler turuncu ve kahverengi jeoloji ve jeomorfoloji çalışmalarıdır. (Şekil 12 ve Çizelge 5).

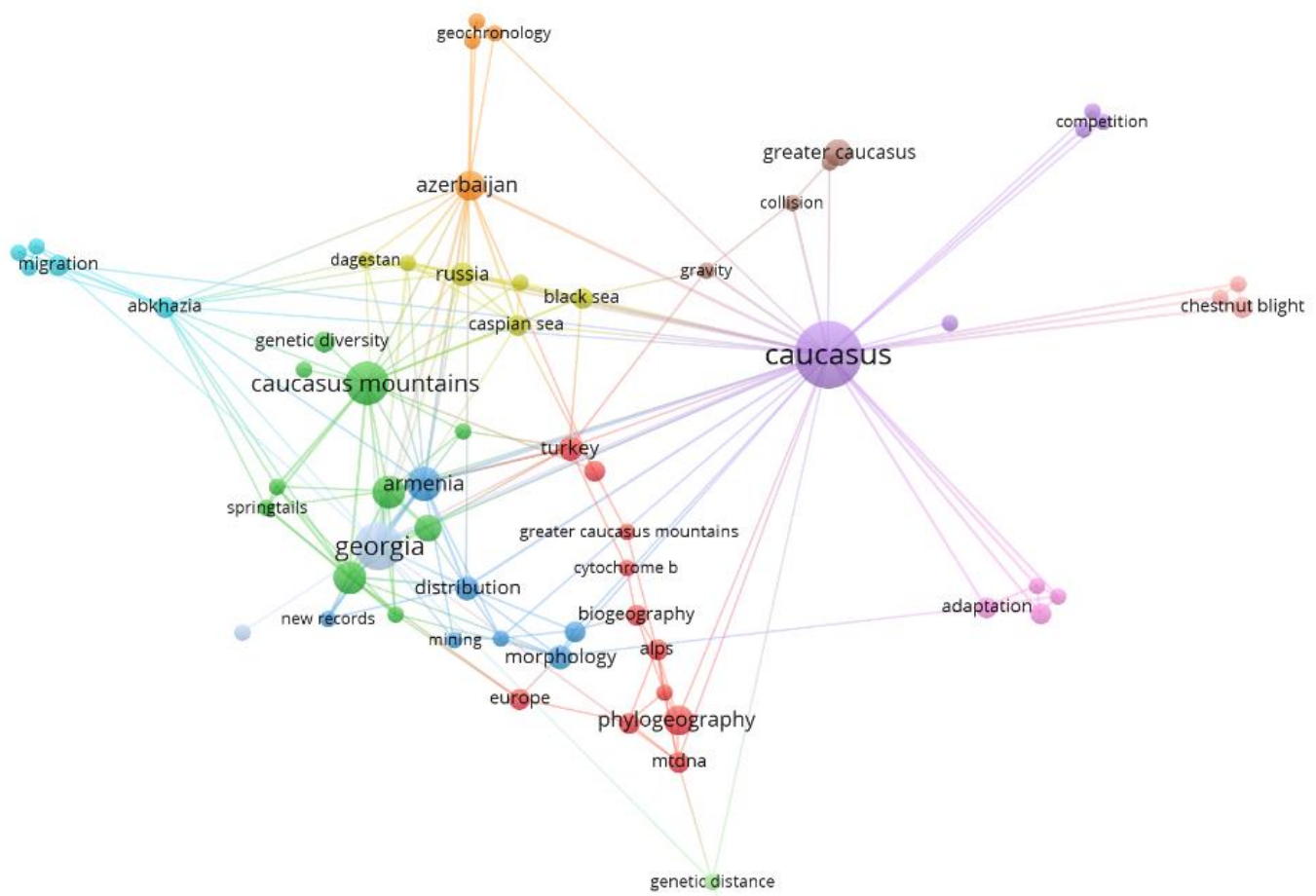

vosviewer

Şekil 12. Anahtar kelimelerde kullanılan kavramların ağ analizi

Çizelge 5. Anahtar kelimelerin sıklığı ve birlikte kullanıldığı terim sayıları

\begin{tabular}{|c|c|c|c|c|c|c|c|}
\hline Sira & Anahtar Kelime & Sıklık & $\begin{array}{c}\text { Birlikte } \\
\text { Kullanıldığı } \\
\text { Terim Sayısı }\end{array}$ & Sura & Anahtar Kelime & Siklık & $\begin{array}{c}\text { Birlikte } \\
\text { Kullanıldığı } \\
\text { Terim Sayısı }\end{array}$ \\
\hline 1 & Kafkaslar (caucasus) & 29 & 60 & 37 & Kıta Çarpışması (collision) & 2 & 4 \\
\hline 2 & Gürcistan (georgia) & 15 & 40 & 38 & Rekabet (competition) & 2 & 3 \\
\hline 3 & Kafkas Dağları (caucasus mountains) & 12 & 20 & 39 & Sitokrom B (cytochrome b) & 2 & 2 \\
\hline 4 & Ermenistan (armenia) & 8 & 25 & 40 & Dağıstan (dagestan) & 2 & 8 \\
\hline 5 & Yeni Türler (new species) & 7 & 19 & 41 & Yaprak Döken Ormanlar (deciduous forests) & 2 & 6 \\
\hline 6 & Taksonomi (taxonomy) & 7 & 23 & 42 & Çeşitlilik (diversity) & 2 & 4 \\
\hline 7 & Azerbaycan (azerbaijan) & 6 & 23 & 43 & Etnisite (ethnicity) & 2 & 5 \\
\hline 8 & phylogeography & 6 & 5 & 44 & Genetik Mesafe (genetic distance) & 2 & 4 \\
\hline 9 & Mayıs Sineği (ephemeroptera) & 5 & 12 & 45 & Jeokronoloji (geochronology) & 2 & 4 \\
\hline 10 & Büyük Kafkaslar (greater caucasus) & 5 & 1 & 46 & $\begin{array}{l}\text { Yer Çekimi (gravity) } \\
\text { Büyük Kafkas Dağları (greater caucasus }\end{array}$ & 2 & 5 \\
\hline 11 & Dağılım (distribution) & 4 & 14 & 47 & mountains) & 2 & 2 \\
\hline 12 & Morfoloji (morphology) & 4 & 9 & 48 & CBS (gis) & 2 & 1 \\
\hline 13 & Rusya (russia) & 4 & 17 & 49 & Otçul (herbivory) & 2 & 3 \\
\hline 14 & Türkiye (turkey) & 4 & 10 & 50 & Hidrodinamik (hydrodynamics) & 2 & 4 \\
\hline 15 & Abhazya (abkhazia) & 3 & 15 & 51 & $\begin{array}{l}\text { Kefir (kefir) } \\
\text { Küçük Kafkas Dağları (lesser caucasus }\end{array}$ & 2 & 0 \\
\hline 16 & Adaptasyon (adaptation) & 3 & 9 & 52 & mountains) & 2 & 6 \\
\hline 17 & $\begin{array}{l}\text { Alpler (alps) } \\
\text { Arabistan-Avrasya Kıtasal CCarpıšması }\end{array}$ & 3 & 7 & 53 & $\begin{array}{l}\text { Yerel Nüfus (local population) } \\
\text { Kafkas Kara Orman Tavuğu (lyrurus }\end{array}$ & 2 & 8 \\
\hline 18 & (arabia-eurasia collision) & 3 & 4 & 54 & mlokosiewiczi) & 2 & 8 \\
\hline 19 & Biyocoğrafya (biogeography) & 3 & 4 & 55 & Madencilik (mining) & 2 & 3 \\
\hline 20 & Karadeniz (black sea) & 3 & 7 & 56 & Musteryen (mousterian) & 2 & 1 \\
\hline 21 & Hazar Denizi (caspian sea) & 3 & 12 & 57 & Neandertaller (neanderthals) & 2 & 1 \\
\hline 22 & Kestane Küfü (chestnut blight) & 3 & 6 & 58 & Yeni Cinsler (new genus) & 2 & 8 \\
\hline 23 & Avrupa (europe) & 3 & 4 & 59 & Yeni Kayitlar (new records) & 2 & 7 \\
\hline 24 & Genetik Çeşitlilik (genetic diversity) & 3 & 1 & 60 & Filojenez (phylogeny) & 2 & 1 \\
\hline
\end{tabular}




\begin{tabular}{|c|c|c|c|c|c|c|c|}
\hline 25 & Göç (migration) & 3 & 7 & 61 & Politen Kromozom (polytene chromosomes) & 2 & 4 \\
\hline 26 & Mitokondriyal DNA (mtdna) & 3 & 7 & 62 & Kırmızı Yonca (red clover) & 2 & 2 \\
\hline 27 & $\begin{array}{l}\text { Pleistosen (pleistocene) } \\
\text { Türlerin Dağilım Modellemesi (species }\end{array}$ & 3 & 5 & 63 & $\begin{array}{l}\text { Döner Dalga Deformasyonu (rotary-wave } \\
\text { deformation) }\end{array}$ & 2 & 4 \\
\hline 28 & distribution model) & 3 & 8 & 64 & Rusya Federasyonu (russian federation) & 2 & 0 \\
\hline 29 & Sistematik (systematics) & 3 & 6 & 65 & Sibirya (siberia) & 2 & 4 \\
\hline 30 & Atmosfer Fiziği (atmospheric physics) & 2 & 4 & 66 & Kaynak Kayaç (source rock) & 2 & 4 \\
\hline 31 & Avusturya (austria) & 2 & 6 & 67 & Güney Hazar Havzası (south caspian basin) & 2 & 3 \\
\hline 32 & Kestane (castanea) & 2 & 6 & 68 & Güney Kafkaslar (south caucasus) & 2 & 1 \\
\hline 33 & Çeçenistan (chechnya) & 2 & 12 & 69 & Yay Kur-yruk Böceği (springtails) & 2 & 9 \\
\hline 34 & Hristiyanlık (christianity) & 2 & 4 & 70 & Subdüksiyon (subduction) & 2 & 3 \\
\hline 35 & Çerkesler (circassians) & 2 & 4 & 71 & Kafkaslar (the caucasus) & 2 & 0 \\
\hline 36 & İklim Değişikliği (climate change) & 2 & 1 & 72 & Troglomorfik (troglomorphic) & 2 & 9 \\
\hline
\end{tabular}

Anahtar kelimelerden elde edilen sıklık ve birlikte kullanılma durumlarına ilişkin bulgular iki farklı boyutta analiz edilmiştir. Analizin ikinci boyutu ise zaman trendidir. Yukarıda elde edilen kümelenme analizindeki varsayımlar geçerli olmak kaydıyla anahtar kelimelerde en çok kullanılan terimlerin zaman trendi elde edilmiştir. Zaman trendi analizinde elde edilen en önemli sonuçlar şunlardır: Özellikle yeni çalışmaların özet ve başlık analizine göre, daha önce görülmeyen etnisite, göç, Hristiyanlık ve adaptasyon gibi yeni sosyal konuların görülmesidir. Aynı zamanda yeni kavramların bir üst analizde belirtilen biyoloji ve ekoloji çalışmalarında yoğunlaştığı görülmektedir. Bir diğer yeni kavramların çalışıldığı küme ise yukarıda belirtilen ve özellikle Rusya'nın öncülüğündeki deniz araştırmalarının olduğu kümedir. Yine jeoloji ve jeomorfoloji çalışmalarının ise daha geleneksel bir konumda olduğu söylenebilir (Şekil 13).

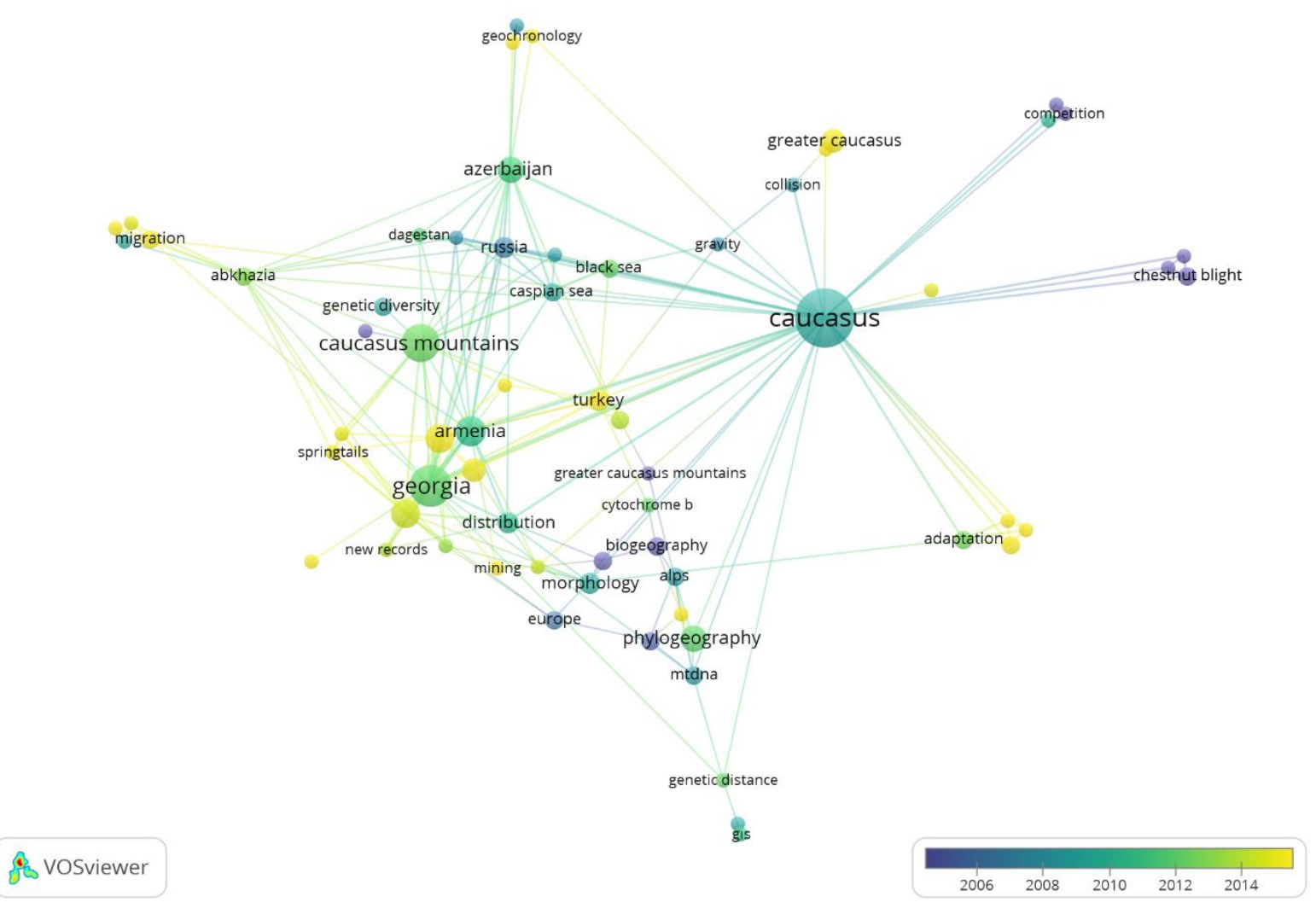

Şekil 13. Anahtar kelimelerde kullanılan kavramların zaman trendi 


\section{Sonuç ve Öneriler}

Araştırmadan elde edilen bulgulara göre, Kafkas Dağları ile ilgili çalışmalar 1980 yılından itibaren, özellikle de SSCB’nin dağıldığı 1991 yılından sonra hızla artmıştır (Şekil 1). Bu zamana kadar sınırlı sayıda yapılan araştırmaların da jeoloji alanında olduğu tespit edilmiştir. Kafkas Dağları'nın jeopolitik önemi ve çatışma unsuru olması nedeniyle SSCB döneminde çalışılmasının mümkün olmadığ1 düşünülebilir. Yayın sayısı bakımından en önemli üç ülke ABD, Rusya ve Gürcistan'dır. Genel olarak bölge ülkelerinin alanla ilgili çalışmaları diğer ülkelere göre daha azdır. Ülkeler arası atıf analizi incelendiğinde de ABD ve Rusya'nın konumunun merkezi olduğu görülmektedir.

Ortak yazar analizinde ABD'nin gerek bölge ülkeleri gerekse diğer ülkeler arasındaki konumunun Rusya'dan daha merkezi olduğu görülmektedir. Özellikle SSBC'nin dağılmasının ardından bölge ülkelerinden bilhassa Gürcistan'ın Bat1 ülkeleriyle iş birliği politikası yürütmesi, bu ülkelerinden araştırmacıların Kafkas Dağları'nda araştırmalar yürütmesine imkân sağlamıştır. Nitekim Kıta Avrupası ülkelerinin bu yıllardan sonra Kafkas Dağları'yla ilgili araştırmalarına rastlanmaktadır. Bölgeye olan ilgideki bu artışın yanında iş birlikleri de yeniden inşa edilmiştir. Buna göre bölge ülkeleri artık daha çok ABD ve Kıta Avrupası ile iş birliği yapmaya başlamıştır buna karşılık bölge ülkeleri arasındaki iş birliği düzeyi düşük kalmıştır.

Şüphesiz yayın sayısı, atıf örüntüsü ve iş birlikleri araştırılan Kafkas Dağları'nın nasıl ve hangi bağlamlarda incelendiğiyle ilgili de fikirler vermektedir. Dolayısıyla bu anlamda yapılan analizlerin odakları çok güçlü teknik bilim geleneğine sahip olan ABD ve Rusya'nın başat rol oynadığını göstermektedir. Yayınlarda anahtar kelimeler, başlık ve özet bölümlerinde en çok kullanılan terimler analiz edilip literatürdeki boşluklar tespit edilmeye çalış1mıştır. Kavramsal terimlerin alansal dağılış1 incelendiğinde ağırlığın doğa bilimleri ve mühendislik alanlarında olduğu tespit edilmiştir. Disipliner dağılımda ise yapılan çalışmaların jeoloji, tektonik ve fiziki coğrafya ekseninde olduğu, sosyal bilimlerin yetersiz olduğu söylenebilir. Fakat SSCB'den sonra bölge ülkelerinin kapalı bilim geleneği dönüşerek yeni çalışma odakları şekillenmiştir. Bu bağlamda artan küreselleşmenin de desteğiyle son yıllarda ortaya çıkan farklı çalışma işbirlikleri Kafkas Dağları konusundaki kavram çeşitliliğinin yetersiz de olsa artmasına vesile olmuştur. Dolayısıyla bu çalışmadan sonra Kafkas Dağları'nın toplumsal anlamda kalkınması için alanın multi-disipliner anlayışla gerek bilim gerekse yönetim anlamında değerlendirilmesi gerekmektedir.

Araştırma her ne kadar nicel veriler ile bazı durumları açıklamış olsa da, gelecek çalışmalarda veri tabanı ve örneklem sayısının arttırılarak kapsamlı bulgulara ulaşılması sağlanabilir. Çünkü literatürde Kafkas Dağlarına ilişkin bibliyometrik analizlerin yapıldığı bir çalışmaya rastlanmamıştır. Bu durum konu ile ilgili yapılacak olan yeni çalışmalar için özgün bir alan oluşturmaktadır.

Araştırma her ne kadar özelde Kafkas Dağları üzerinde bir çalışma olsa da genelde araştırma alanı olarak dağlık alanlarla ilgilidir. Dolayısıyla gerek coğrafya içerisinde gerekse dışındaki ilgili disiplinlerde meselenin nasıl ele alınabileceğiyle ilgili fikirler vermektedir. Ayrıca ülkemizdeki diğer dağlık alanların üzerinde nasıl ve hangi çalışmaların olabileceğiyle ilgili de bu çalışmadan fikir yürütülebilir. Buradan hareketle yapılacak coğrafya araştırmaları literatürdeki boşlukları doldurması ve yeni eğilimleri yakından takip imkânı verecektir. 
Araştırma yine coğrafyanın farklı alanları için de uygulanabilir bir metot barındırmaktır. Bu nedenle yeni araştırmacıların ilgi alanlarında nasıl bir yol izleyebileceği bakımından bir metot olarak önerilmektedir.

\section{Notlar}

1. Düğümler insanları, nesneleri yani aktörleri, kenarlar ise bağlantıları temsil eder. Bundan dolayı sosyal ağ analizinde; aktörlerin, nesnelerin özelliklerinden ziyade, bireyler, gruplar veya nesneler arası ilişkilere odaklanılması, bu analizi sosyal bilimlerde kullanılan diğer yöntemlerden ayıran önemli bir özelliktir (Kervankıran, Sert Eteman ve Çuhadar, 2018, s.32).

2. SSCB, 1922 kurulmuş ve 1991 yılına kadar varlığını sürdürmüştür. 1991 yılı öncesinde Kafkas Dağları konusunda yayın sayısı fazla olmasından dolayı dikkat çekmektedir (Tablo 1). 1991 yılında SSCB'nin yıkılmasıyla kurulan Rusya, Azerbaycan, Gürcistan, Ermenistan ve Ukrayna yine Kafkas Dağları konusunda bölge ülkeleri olarak önemli bir yer teşkil etmektedir.

\section{Teşekkür ve Bilgilendirme}

Bu çalışma 2019 yılında düzenlenen "Second Caucasus Mountain Forum: The Caucasus Research Agenda - a Key to Sustainable Regional Development” isimli bilimsel etkinlik çerçevesinde sözlü olarak sunulmuştur. Bu araştırma esnasında fikir ve görüşleriyle katkı sağlayan Dr. Öğr Üyesi Muhittin Kulak'a teşekkür ederiz. 
To cite: Güney, İ., Altundal Öncü, M., Somuncu, M. (2020). New Research Trends for the Caucasus Mountains: A Bibliometric Analysis, Coğrafi Bilimler Dergisi/ Turkish Journal of Geographical Sciences, 18(2), 161-190, doi: 10.33688/ aucbd.710750.

$\begin{array}{ccc}\text { Coğrafi Bilimler Dergisi } & \text { Coğrafi } \\ \text { Bilimler } \\ \text { Dergisi }\end{array}$

\section{New Research Trends for the Caucasus Mountains: A Bibliometric Analysis} İsmet Güney*a ${ }^{* a}$ Merve Altundal Öncü ${ }^{\mathrm{b}}$, Mehmet Somuncu ${ }^{\mathrm{c}}$

\section{EXTENDED ABSTRACT}

\section{Introduction}

In this research, macro-scale topics, disciplinary distribution, regional distribution and citation pattern of international studies investigating the Caucasus Mountains as a scientific object were analyzed. With this study, it is aimed to guide new actors working in the related field, both within and outside geography, by examining leading actors and new concepts in the researches related to the Caucasus Mountains. In this context, the answer to the following basic question was sought throughout the research: What is the current development of the literature on the Caucasus Mountains and in which direction will it evolve in the future? In order to answer this research question, the following subquestions were investigated: In which countries are researchers interested in the Caucasus Mountains? What are the main concepts and new themes on the Caucasus Mountains? What are the spatial distribution and disciplinary distribution of researches or researchers? Which authors are being referred in the researches on the Caucasus Mountains and where is the new focus regarding cooperation? In order to answer these questions, network analyzes were done through bibliometric indicators. In the title, summary and keywords section of Scopus database, the works containing the term "Caucasian Mountains" are listed. Findings obtained according to the results of the analysis were evaluated within the context of actors and concepts. The most important motivation of the research is that there is no previous literature analysis with the bibliometric analysis method related to the Caucasus Mountains.

\section{Methodology}

In order to evaluate new trends in the Caucasus Mountains, the data on the content, author and origin information of the publications were obtained from the Scopus citation index. 327 documents containing the word "caucasus mountains" in the title, summary and keywords sections were obtained in the database on October 2, 2019 and were analyzed by bibliometric network analysis. The first type of data obtained for the purpose of the research is bibliometric data including citation, author and address information. The second type of data obtained for the purpose of the research is content data consisting of titles, abstracts and keywords related to the subjects of the works.

\footnotetext{
*Corresponding Author: ismetguney@kilis.edu.tr

${ }^{a}$ Kilis 7 Aralık University, Faculty of Arts and Sciences, Department of Geography, Kilis/Turkey, http://orcid.org/00000003-4682-4905

b Ankara University, Faculty of Languages, History and Geography, Department of Geography, Ankara/ Turkey, http://orcid.org/0000-0003-2402-9134

c Ankara University, Faculty of Languages, History and Geography, Department of Geography, Ankara/ Turkey, http://orcid.org/0000-0001-8890-0537
} 
With the help of VOSviewer, visualized findings were interpreted according to frequency, relationality, clustering and time analysis. Frequency is the frequency of the text and bibliometric data that constitute the units of analysis in network maps obtained as a result of assumptions. Relationality refers to the level of relationality between the bibliometric data determined by frequency, that is, the state of coexistence. Accordingly, units with high relationality are transferred to the network map by the program, while units with low relationality are excluded. Examples of bibliometric data with high levels of interest are; while it tends to represent certain topics covered by text data, low-interest terms have a general structure and do not represent a particular topic. By excluding terms of low interest, general terms are filtered and focus shifts to more specific and more informative terms. Then, in cluster analysis, the actors / units called nodes and the relationships that connect these node pairs are analyzed. The cluster of all nodes and relationships between binary nodes is called a social network. Nodes can be individuals, groups, institutions, or countries. Relationships are the joint work of these nodes with each other (Al et al., 2012; Tindall and Wellman, 2001). Finally, with the trend of time analysis, the progression of the periodically prominent subjects in other periods and the thematic areas created by them are shown on the map. The publication dates were used to identify the thematic areas featured here. In this case, temporal longitude analysis is possible.

\section{Result}

In the citation network analysis, an analysis was made on which source country the citations made in the bibliography based on the address information of the responsible authors of the works. Findings related to the frequency and citation relationship between them were analyzed in two different dimensions. The first is the cluster size. According to this analysis, 7 clusters with many citation relationships were identified. The first cluster (red) includes Canada, Japan, China, Spain and Switzerland. The closest cluster the first cluster group refers to most is the seventh cluster represented by orange circles. While the USA is the focus of this cluster, its second element is Italy. Therefore, it can be said that the first and seventh clusters are close in terms of attribution relations. Another close cluster to this group is the third cluster represented in blue, with its focus in France. Other countries are Azerbaijan and the Netherlands. The second cluster (green) focus is Germany. Other principles in this cluster are Poland and the Czech Republic. It is the fifth cluster represented by the purple color with the closest attribution relationship of the second cluster, with Russia at its center. Other countries are England and Austria. This is the fourth set close to the other cluster group (brown) and Turkey, Armenia and Greece. Another close cluster to the fifth cluster is the sixth cluster (blue) with Georgia and Iran. According to these results, citation preferences are grouped around the USA and Russia. According to the citation analysis made, it is seen that the countries with the most broadcasting have the most cited studies. Looking at the citation cluster in the literature on the subject of the research, it is seen that the countries of the region cite each other. Despite the low level of cooperation and the number of publications, it is determined that Caucasian countries are included in the same citation set or neighbor citation sets. This shows that the countries of the region follow each other in the literature (Figure 1a). The second dimension of the analysis is the time trend. The time trend of the citation pattern has been obtained, provided that the assumptions in the cluster analysis obtained above are valid. The most 
important result obtained in the time trend analysis is the detection of Ukraine, Poland, Azerbaijan, China and Iran as new citation points (Figure 1b).

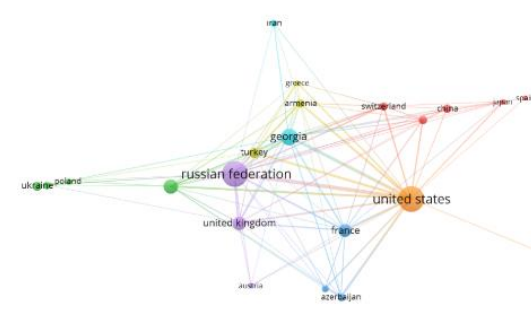

A vosviewer

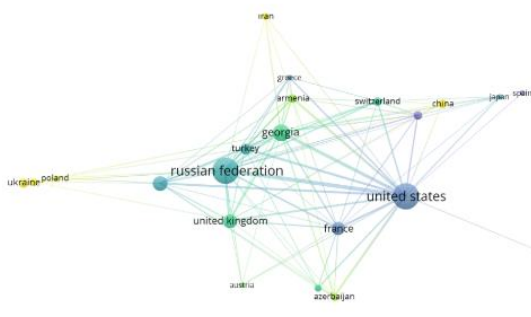

As vosviewer

Figure 1. Citation network map (a) and citation trend (b) by country

The findings regarding the frequency and co-authorship cases were analyzed in two different dimensions. The first is the cluster size. It is for which countries the co-authors are in the works. Accordingly, 8 clusters have been identified. The first cluster (red) focus is France. The second cluster (green) focus is Switzerland. The third cluster (blue) focus includes England, Germany and Georgia. The fourth cluster (yellow) Turkey is located at the focal point. The fifth cluster (purple) focus is in the USA and this cluster is at the center of the previous four clusters, taking the lead of a large cluster group. In other words, it is seen that the first five clusters have more practice of working together. The sixth cluster (turquoise) is located in the center of Russia and represents the other block in the network map. It is the seventh cluster formed by Armenia and Serbia, which cooperate closely with this cluster. The eighth cluster is in the center of Canada and is close to the fifth cluster (Figure 2a). The second dimension of the analysis is the time trend. Provided that the assumptions in the cluster analysis obtained above are valid, the time trend of the most common relations in co-authoring between countries has been obtained. The most important results obtained in the time trend analysis are as follows: When the new collaboration trends are analyzed in the time trend based on the cooperation between the authors, it is seen that the most important partners are Ukraine, Iran, Romania, China and Belgium (Figure 2b). 


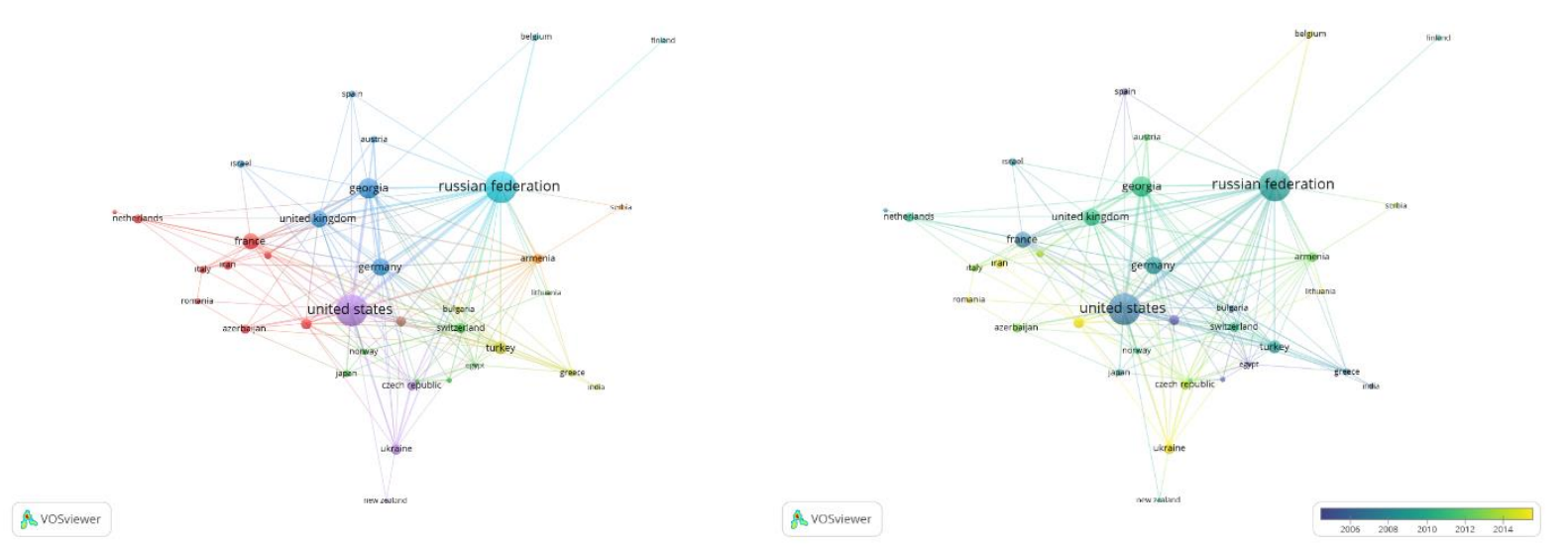

Figure 2. Network map based on co-authorship between countries (a) and time trend (b)

The summary and the textual data in the header obtained from the Scopus database were analyzed according to their co-occurrence. Findings related to the frequency obtained and their use were analyzed in two different dimensions. The first is the cluster size. The most important results from this analysis are as follows: 4 sets of terms are formed. The first set includes mostly biology and natural environment studies, which are shown in red. The concepts that have the highest relationality and frequency are gene flow, population, origin, etc. The second cluster is shown in green and it is observed that geology and geomorphology studies are dominant. The concepts, where the relationality and frequency are the highest, are deformation, zone, sediment, observation etc. The third cluster is shown in blue and consists of ecology studies. Particularly important subjects were the climate change, forest and land assets. The fourth cluster is shown in yellow and is located as the transition cluster between the first and third clusters. While red, blue and yellow clusters have high relationality and common term usage among them, the green cluster distinguishes significantly from other research clusters. The fact that the concepts related to the social sciences are low in this area shows that the studies dealing with the social dimension of the Caucasian mountains phenomenon are few (Figure 3a). The most important results obtained in the time trend analysis are as follows: It can be said that especially new studies are concentrated in the field of ecology. In this context, it has been determined that new terms are density, new species, Asia, gene flow, genetic diversity, Armenia, habitat and origin. It can be said that geology and geomorphology studies are in a more traditional position (Figure 3b). 

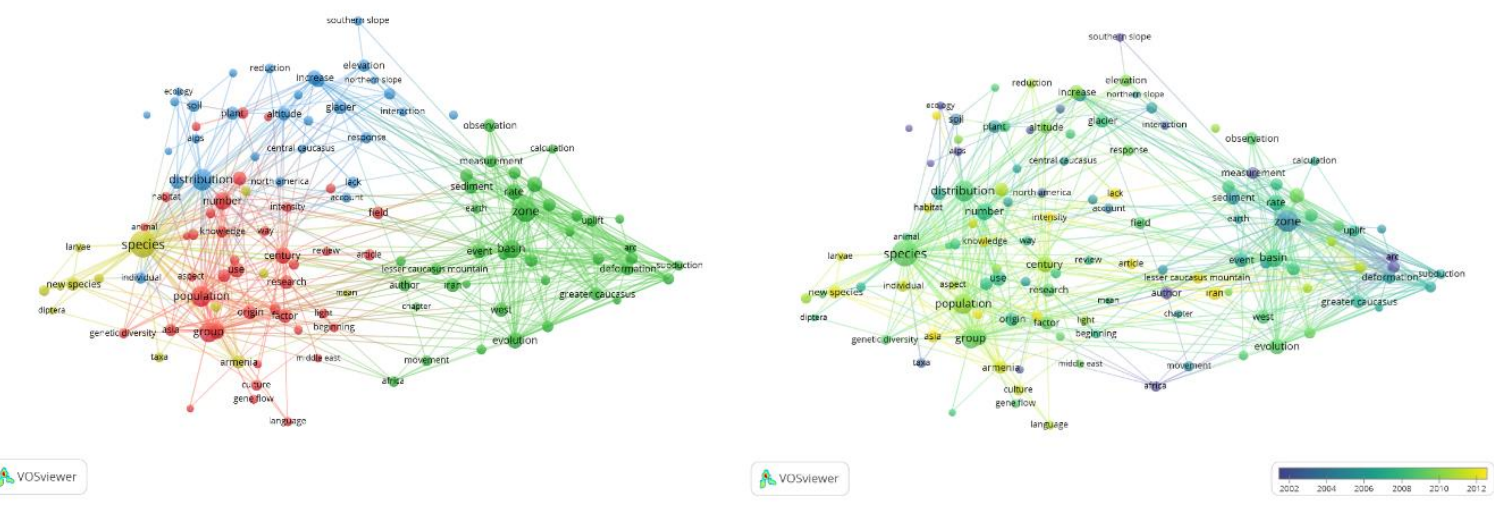

Figure 3. Network analysis of the most used terms in the summary and titles (a) and time trend (b)

\section{Discussion and Conclusions}

Although the research has explained some situations with quantitative data, it can be ensured to reach comprehensive findings by increasing the number of databases and samples in future studies. Although the research is a study on the Caucasus Mountains in particular, it is generally related to mountain areas as a research area. Therefore, it gives ideas about how the issue can be handled both within geography and other related disciplines. In addition, the idea of how and what works can be done on other mountainous areas in our country can be carried out from this study. The research is also to include a feasible method for different areas of geography. Therefore, it is proposed as a method in terms of how new researchers can follow their interests.

\section{Referanslar/References}

Al, U. (2008). Türkiye'nin Bilimsel Yayın Politikası: Atıf Dizinlerine Dayalı Bibliyometrik Bir Yaklaşım. Hacettepe Üniversitesi, Sosyal Bilimler Enstitüsü, Yayımlanmamış Doktora Tezi, Ankara. https://tez.yok.gov.tr/UlusalTezMerkezi/tezSorguSonucYeni.jsp adresinden edinilmiştir.

Al, U., Tonda, Y. (2004). Atıf Analizi: Hacettepe Üniversitesi Kütüphanecilik Bölümü Tezlerinde Atıf Yapılan Kaynaklar. Bilgi Dünyasl, 5 (1), 19-47. http://yunus.hacettepe.edu.tr/ umutal/publications/citationanalysis.pdf adresinden alınd.

Al, U., Sezen, U. ve Soydal, İ. (2012). Türkiye'nin Bilimsel Yayınlarının Sosyal A $\breve{g}$ Analizi Yöntemiyle Değerlendirilmesi. TÜBİTAK Social Sciences and Humanities Research Group-Project No: SOBAG 110K044). Ankara. http://www.openaccess.hacettepe.edu.tr:8080/xmlui/handle/11655/11897 adresinden alınd1.

Ayan, S., Öztürk, S. ve Yiğit, N. (2009). Karadeniz Bölgesi Milli Parklarının Korunan Alan Ağı Sertifikalandırma Sistemine Uygunlukları. Kastamonu Üniversitesi Orman Fakültesi Dergisi, $9 \quad$ (1), 66-79. https://dergipark.org.tr/en/pub/kastorman/issue/17240/180111 adresinden alındı.

Bekaroğlu, E., Yavan, N. (2013). Modern Türk Coğrafyasının Tarihsel Gelişiminde Batılı Coğrafya Okullarının Etkisi: Ampirik Bir Analiz. Beşeri Coğrafya Dergisi, 1 (1), 51-66.

https://www.academia.edu/7313746/Modern_T\%C3\%BCrk_co\%C4\%9Frafyas\%C4\%B1n\%C4\%B1n_tarihsel_geli\% C5\%9Fiminde_Bat\%C4\%B11\%C4\%B1_co\%C4\%9Frafya_okullar\%C4\%B1n\%C4\%B1n_etkisi_Ampirik_bir_analiz_ Influences_of_Western_Geography_on_the_Historical_Development_of_Modern_Turkish_Geography_An_Empirica l_Analysis_adresinden alınd.

Beniston, M. (2000). Environmental Change in Mountains and Uplands. London: Oxford University Press.

Dal, N., Gönençgil, B. (2018). Türkiye'de Dağ ve Dağlık Alan Sınırlandırması İçin Bir Yaklaşım, TÜCAUM 30. Yıl Uluslararası Coğrafya Sempozyumu Bildirileri içinde (907-913). Ankara. 
Ertoy, M., Yalçın, H. (2017). Bauman'ın Sosyolojisi ve (Sosyal) Bilime Bıraktığı Miras. Süleyman Demirel Üniversitesi FenEdebiyat Fakültesi Sosyal Bilimler $\quad$ Dergisi, $\quad$ (42), https://dergipark.org.tr/tr/pub/sufesosbil/issue/33853/334843 adresinden alınd1.

Estevão, C. M., Garcia, A. R., Filipe, S. B., Muniz, A. C. F. (2017). Convergence in Tourism Management Research: A Bibliometric Analysis. Tourism \& Management Studies, $13 \quad$ (4), 30-42. https://www.researchgate.net/publication/322323138_Convergence_in_tourism_management_research_a_bibliomet ric_analysis adresinden alınd.

Freeman, L.C. (2004). The Development of Social Network Analysis: A Study in The Sociology of Science. Vancouver: Empirical Press.

Garfield, E. (1979). Citation Indexing: Its Theory and Application in Science, Technology, and Humanities. Philadelphia: ISI Press.

Garfield, E. (1988). Announcing The SCI Compact Disk Edition- CD-ROM Gigabyte Storage Technology, Novel Software, and Bibliographic Coupling Make Desktop Research and Discovery A Reality. Current Contents, (22), 3-13. http://garfield.library.upenn.edu/essays/v11p160y1988.pdf adresinden alınd1.

Glänzel, W., Schubert, A. (2005). Analyzing Scientific Networks Through Co-Authorship. F. H. Moed, W. Glänzel ve U. Schmoch (Ed.), Handbook of Quantitative Science and Technology Research içinde (257-276). Dordrecht: Kluwer Academic Publishers.

Güney, İ., Somuncu, M. (2017). Coğrafyacıların Turizm Disiplinine Akademik Katkıları: "Annals of Tourism Research" Dergisi Üzerinden Betimsel Bir Analiz. Journal of International Social Research, 10 (54), 453-463. http://www.sosyalarastirmalar.com/cilt10/sayi54_pdf/3sanattarihi_arkeoloji_cografya/guney_ismet.pdf adresinden alındi.

Hall, C. M. (2011). Publish and Perish? Bibliometric Analysis, Journal Ranking and The Assessment of Research Quality in Tourism. Tourism Management, 32 (1), 16-27. doi: 10.1016/j.tourman.2010.07.001.

Karagöz, D., Kozak, N. (2014). Anatolia: Turizm Araştırmaları Dergisi'nin Bibliyometrik Analizi: Araştırma Konuları ve Kurumlar Arası İș Birliğinin Sosyal Ağ Analizi ile İncelenmesi. Türk Kütüphaneciliği, 28 (1), 47-61. https://dergipark.org.tr/tr/download/article-file/811301 adresinden alındı.

Kervankıran, İ., Eteman, F. S., Şardağ, A. (2019). Türkiye'de Turizm Coğrafyası Araştırmalarında Disipliner İlişkinin Sosyal Ağ Analizi ile İncelenmesi. Gaziantep University Journal of Social Sciences, 18 (3), 938-965. doi: 10.21547/jss.558270

Kervankıran, i., Eteman, F. S., Çuhadar, M. (2018). Türkiye'de İç Turizm Hareketlerinin Sosyal A $\breve{g}$ Analizi ile İncelenmesi. Turizm Akademik Dergisi, 5 (1), 28-49. https://dergipark.org.tr/tr/download/article-file/496555 adresinden alınd1.

Kuhzady, S., Benli, R. A. S. (2017). Toward A New Paradigm in Sustainable Tourism: Trend and Pattern Analysis in Tourism Resilience Researches. 1 st International Sustainable Tourism Congress içinde (974-980), Kastamonu.

Kulak, M., Ozkan, A., Bindak, R. (2019). A Bibliometric Analysis of The Essential Oil-Bearing Plants Exposed to The Water Stress: How Long Way We Have Come and How Much Further?. Scientia Horticulturae, 246, 418-436. doi: 10.1016/j.scienta.2018.11.031.

Kulak, M., Cetinkaya, H. (2018). A Systematic Review: Polyphenol Contents in Stressed-Olive Trees and Its Fruit Oil. Polyphenols, 1. doi: 10.5772/intechopen.76703.

McKercher, B. (2008). A Citation Analysis of Tourism Scholars. Tourism Management, 29 (6), 1226-1232. doi: 10.1016/j.tourman.2008.03.003.

Metin, T. C. (20013). Boş Zaman Literatürünün Dünyadaki Gelişimi: Leisure Science Dergisinde Yayımlanan Makaleler Üzerine Bir Ínceleme, Anadolu Üniversitesi, Sosyal Bilimler Enstitüsü, Yayımlanmamış Yüksek Lisans Tezi, Eskişehir. https://tez.yok.gov.tr/UlusalTezMerkezi/tezSorguSonucYeni.jsp adresinden alındı.

Morris, S. A., Van der Veer Martens, B. (2008). Mapping Research Specialties. Annual Review of Information Science and Technology, 42, 213-295. https://www.researchgate.net/publication/220141981_Mapping_research_specialties adresinden alınd1.

Mountain Agenda. (1998), Mountains of the World: Water Towers for the 21st Century, Bern: Mountain Agenda. https://pdfs.semanticscholar.org/6915/f9a653ed090dd5610381afdd00066c96383e.pdf adresinden alind1.

Mountain Agenda. (1999), Mountains of the World: Tourism and Sustainable Mountain Development, Bern: Mountain Agenda.

Payne, K., Warrington, S., Bennett, O. (2002). High Stakes: The Future for Mountain Societies, London: Panos Institute. http://panoslondon.panosnetwork.org/resources/high-stakes/adresinden alınd. 
Rodriguez, M., Pepe, A. (2008). On The Relationship Between The Structural and Socioacademic Communities of A CoAuthorship Network. Journal of Infometrics, 2 (3), 195-201. doi: 10.1016/j.joi.2008.04.002.

Scott, J. P. (2000). Social Network Analysis A Handbook. (2nd ed.). London: Sage Publications.

Somuncu, M. (2004). Dağcılık ve Dağ Turizmindeki İkilem: Ekonomik Yarar ve Ekolojik Bedel. Coğrafi Bilimler Dergisi, 2 (1), 1-21. doi: 10.1501/Cogbil_0000000041.

Tindall, D.B., Wellman, B. (2001). Canada As Social Structure: Social Network Analysis and Canadian Sociology. The Canadian Journal of Sociology, 26, 265-308. https://www.jstor.org/stable/pdf/3341889.pdf adresinden alınd1.

Van Eck, N., Waltman, L. (2010). Software Survey: Vosviewer, A Computer Program for Bibliometric Mapping. Scientometrics, 84 (2), 523-538. https://link.springer.com/article/10.1007/s11192-009-0146-3 adresinden alınd.

Yildiz, T., Aykanat, Z. (2017). Psikolojik Sözleşme Kavramının Evrimsel Gelişiminin Bilimsel Haritalama Yöntemiyle İncelenmesi. Çanakkale Onsekiz Mart Üniversitesi Yönetim Bilimleri Dergisi, $15 \quad$ (29), 243. http://acikerisim.lib.comu.edu.tr:8080/xmlui/handle/COMU/1708 adresinden alındı.

Yüncü, D. K., N. Kozak. (2012). Anatolia Turizm Araştırmaları Dergisi'nin Bibliyometrik Analizi: Araştırma Konuları ve Kurumlar Arası İșbirliğinin Sosyal Ağ Analiz ile İncelenmesi, VI. Lisansüstü Turizm Öğrencileri Araștırma Kongresi Bildiriler içinde (642-660). Antalya.

Zan, B.U. (2012). Türkiye'de Bilim Dallarında Karşılaştırmalı Bibliyometrik Analiz Çalışması. Ankara Üniversitesi, Sosyal Bilimler Enstitüsü, Yayımlanmamış https://tez.yok.gov.tr/UlusalTezMerkezi/tezSorguSonucYeni.jsp adresinden alınd. 